\title{
A new variant of the human a-lactalbumin-oleic acid complex as an anticancer agent for chronic myeloid leukemia
}

\author{
Vivek Singh ${ }^{1}$, Ranjana Singh ${ }^{1 *}$, Dinesh Kumar ${ }^{2}$, Abbas Ali Mahdi ${ }^{1}$, Anil Kumar Tripathi ${ }^{3}$
}

\author{
Author Affiliations: \\ 1. Department of Biochemistry, King George's Medical University, \\ Lucknow, Uttar Pradesh, India \\ 2. Centre of Biomedical Research, Sanjay Gandhi Post-Graduate Institute of \\ Medical Sciences, Lucknow, Uttar Pradesh, India \\ 3. Department of Clinical Hematology, King George's Medical University, \\ Lucknow, Uttar Pradesh, India
}

\begin{abstract}
Chronic myeloid leukemia (GML) is a clonal myeloproliferative disorder of hematopoietic stem cells. Although there have been advancements in treatment, there is still a need to develop a biotherapeutic agent. A new variant of the human alpha-lactalbumin-oleic acid (HALOA) complex has been synthesized, which showed similarities with SNARE. The native a-LA was treated with EDTA to remove $\mathrm{Ca}^{2+}$ ions confirmed by ICP-OES and Arsenazo III to unfold and attain apo structure. The apo LA was mixed with $\mathrm{OA}$ in a specific ratio, leading to HALOA complex formation. The conformational state from native to complex was elucidated by circular dichroism (far; 190-260 nm and near; 260-340 nm UV-CD), which confirmed that the complex consists of a majority of turns and $\beta$-sheet structure. SDS-PAGE result showed the masking effect of OA on apo a-LA. In the lane of the complex, there was no band detected. However, 1-anilino-8-naphthalene sulfonate (ANS) dye has shown maximum fluorescence intensity with the complex because of the availability of hydrophobic patches, which was further validated by NMR spectroscopy indicating the masking effect of OA on the apo a-LA. The SNARE behavior of the complex (500 nm) has been confirmed by TEM. This new structural variant complex shows anti-tumor activity on chronic myeloid leukemia by targeting the IL-8, survivin, and induces apoptosis through DNA fragmentation, but not against normal cells. Overall, the formulated complex shows that SNARE-like behavior can be used as a promising anti-tumor agent with lower toxicity and maximum bioavailability.
\end{abstract}

KEYWORDS: Alpha-lactalbumin, Oleic acid, Chronic myeloid leukemia, SNARE, IL-8, Survivin.

ABBREVIATIONS: HALOA - Human a-Lactalbumin-Oleic Acid; EDTA-Ethylenediaminetetraacetic acid;ICP-OES-Inductivelycoupled plasma-optical emission spectrometry; UV-CD - Ultraviolet-Circular Dichroism spectroscopy; SDS-PAGE - Sodium dodecyl sulfate polyacrylamide gel electrophoresis; OA - Oleic acid; ANS - 1-anilino8-naphthalene sulfonate; NMR - Nuclear Magnetic Resonance; TEM - transmission electron microscopy; IL-8 - Interleukin 8; SNARE's - SNAP Receptor; CML - Chronic myeloid leukemia; MTT - 3-(4,5-dimethylthiazol-2-yl)-2,5-diphenyl tetrazolium bromide.

\author{
* Corresponding Author: \\ Ranjana Singh, \\ Department of Biochemistry, \\ King George's Medical University, Lucknow, \\ Uttar Pradesh, India-226003. \\ E-mail: ranjanasingh.2509@rediffmail.com; \\ ranjanasingh@kgmcindia.edu
}

DOI

10.25122/jml-2021-0065

Dates

Received: 10 April 2021

Accepted: 9 June 2021 


\section{JOURNAL of MEDICINE and LIFE}

\section{INTRODUCTION}

Human alpha-Lactalbumin (a-LA) is a calcium-binding protein (14.2 kDa), which has neutraceutical values [1]. A new paradigm focuses on its capacity to interact with oleic acid $(\mathrm{OA})$, forming a protein-lipid complex with a property to trigger apoptosis in tumor cells [2-9]. Some studies have already reported that altering the temperature and $\mathrm{pH}$ of a-LA attains the molten globule (MG) conformation upon binding with OA [10-17]. Several studies originated and inspired by the Svanborg laboratory mention that this active complex was developed by chromatographic procedures, not by mixing two components [18]. However, few studies [18, 19] have inferred that the mixing process could produce a complex at lower $\mathrm{pH}$ conditions that display conformation and biological properties similar to the complex formed by Svanborg through chromatographic procedures.

Chronic myeloid leukemia (CML) is a clonal myeloproliferative disorder. The cure rates of CML have improved, but resistance to drugs leads to recurrence, causing death in $50 \%$ to $95 \%$ of patients. In addition, CML patients frequently suffer from secondary neoplasms and chronic health-related problems [20]. Survivin (inhibitor of apoptosis) plays a crucial role in cell proliferation and apoptosis [21, 22]. Increased expression of survivin leads to hematopoietic malignancies [23]. Previous studies indicated that the anti-apoptotic marker survivin tightly regulates most leukemia cells present in the G2/M phase. Survivin interacts with the non-homologous end joining (NHEJ) DNA repair complex that maintains the integrity of the genome in cancer cells and leads to inflammation (IL-8 production) [24-26]. IL-8 represents one of the neutrophil chemotactic activating factors. IL-8 production is induced by oxidative stress, while antioxidant therapy inhibits the IL-8 level [27-30]. To our knowledge, the complex is formed by mixing apo a-LA with OA at neutral $\mathrm{pH}$ (7.4). However, structural similarity with SNARE's complex has not been reported. We aimed to (1) make a new variant of the protein-lipid complex at neutral pH for CML treatment and (2) elucidate the effect of the HALOA complex on the markers of apoptosis (total antioxidant capacity, IL-8, and survivin) on leukemia cells.

\section{MATERIAL AND METHODS}

Materials used in this study are Human a-lactalbumin (Sigma), oleic acid (Sigma), G25 Sephadex (Sigma), ANS (Sigma), RPMI-1640 media (Gibco), antimycotic and antibacterial (Thermo fisher), FBS (Gibco), MTT assay (ab21 1091 MTT Cell Proliferation Assay Kit), Trypan blue (Thermo), Giemsa (Sigma), Hoechst dye (ab228551 Hoechst 33342), DNA Fragmentation kit (TaKaRa 6137) TAC kit (sigma), Annexin V-FITC assay (Milentyi), EdU Assay (Abcam), Survivin assay (Abcam).

\section{HALOA complex formation}

First, 25 milligrams of native human a-LA were solubilized in $1.8 \mathrm{mM}$ in Tris $(10 \mathrm{mM}$ Tris. $\mathrm{Cl}$ at $\mathrm{pH}$ 7.4) at room temperature. Furthermore, we added $3.5 \mathrm{mM}$ EDTA, which helped remove bound $\mathrm{Ca}^{2+}$ from native a-LA and pass through a gel filtration column $(\mathrm{G}-25$ Sephadex column). After proper elution with Tris buffer at pH 7.4, we obtained an apostate of a-LA. The concentration of a-LA (native, apo, and complex) was measured using the Nanodrop at $280 \mathrm{~nm}$ wavelengths, and apo a-LA without calcium ion was lyophilized. Following this, apo a-LA was dissolved in DPBS at pH 7.4 during dissolution; the protein sample was incubated at $37^{\circ} \mathrm{C}$ for 10 minutes to maintain apo-form integrity at $\mathrm{pH}$ 7.4. We obtained $5 \mathrm{mM}$ oleic acid stock solution by blending OA solution in chloroform - DOPS (1, 2-dioleoyl phosphatidylserine) and DOPC (1, 2-dioleoyl phosphatidylcholine); in 30:70 mol/mol ratios in falcon tube (15 mL). OA solution was dried with a gentle shower of nitrogen and resuspended in DPBS at a pH of 7.4. HALOA complex was formulated by simply mixing apo a-LA $(1 \mathrm{mg} / \mathrm{mL})$ with $\mathrm{OA}(1 \mathrm{mg} / \mathrm{mL})$ in a $1: 1$ ratio at $\mathrm{pH} 7.4$, vortexing for $10 \mathrm{~min}$ at $37^{\circ} \mathrm{C}$ for better dissolution. The absorbance of the complex was taken at $200-900 \mathrm{~nm}$ at a different concentration, and further validated by different biophysical techniques, as explained below.

\section{Circular dichroism (CD) for structural characterization}

CD spectrum was procured by JASCO J-1500 spectropolarimeter. Quartz cuvettes with $10 \mathrm{~mm}$ path length were used, and a CD spectrum was recorded from wavelength $190 \mathrm{~nm}$ to $320 \mathrm{~nm}$. The wavelength step was $1 \mathrm{~nm}$, the scan rate was $10 \mathrm{~nm} / \mathrm{min}$, and the response time was $4 \mathrm{~s}$. A total of three scans were recorded and taken on average for each spectrum. In addition, baseline spectra were recorded with DPBS in each cuvette and subtracted from the CD spectra of native a-LA, apo a-LA, and HALOA complex.

\section{ANS fluorescence spectroscopy for confirmation of exposed hydrophobic patches on protein}

ANS fluorescence emission spectra were procured at $25^{\circ} \mathrm{C}$ on a Perkin-Elmer spectrometer using a quartz cuvette with a $1 \mathrm{~cm}$ excitation path length, from $400 \mathrm{~nm}$ to $600 \mathrm{~nm}$ wavelength range excitation wavelength at $385 \mathrm{~nm}$. Both the excitation and emission bandpass were set to $5 \mathrm{~nm}$. Stock solutions were prepared by dissolving native a-LA, apo a-LA, and HALOA complex in $10 \mathrm{mM}$ potassium phosphate buffer at $\mathrm{pH}$ 7.4. The concentrations were depicted by amino acid analysis after acid hydrolysis, and spectra were recorded on aliquots diluted in $10 \mathrm{mM}$ potassium phosphate buffer at $\mathrm{pH} 7.4$. 


\section{JOURNAL of MEDICINE and LIFE}

\section{SDS-PAGE for the integrity of the protein}

Native a-LA, apo a-LA, and HALOA complex were separated using SDS-PAGE. Then, we prepared 4-5\% stacking and $12 \%$ resolving gels and subjected them to electrophoresis following the standard protocol [31].

\section{Inductively coupled plasma optical emission spectrometry (ICP-OES) for metal $\left(\mathrm{Ca}^{2+}\right)$ detection.}

Calcium ion was analyzed from protein samples (Native, apo alpha-lactalbumin, and HALOA complex) diluted in a 1:3 ratio. Multi-element standard (Perkin Elmer pure plus, USA) stock solution $1000 \mathrm{mg} / \mathrm{L}$ was used to prepare calibration standard solution at a different concentration at 0.005 to $1 \mathrm{mg} / \mathrm{L}$. The clear solution obtained after acid digestion was kept in precleaned tubes after cooling. The sample was analyzed by using ICP-OES (Optima 8000, Perkin Elmer) at three different time periods. Instrumental conditions for calcium analysis are given in Table 1.

\section{Arsenazo-IIl used for Calcium ion removal from protein}

We added $20 \mu \mathrm{L}$ of native a-LA, apo a-LA, and HALOA complex to $2 \mathrm{ml}$ of reagent consisting of boric acid-KG1- NaOH buffer, $50 \mathrm{mmol} / \mathrm{L}$, pH 7.4, to contain per liter. Arsenazo-III, $0.08 \mathrm{~g} 8 \mathrm{HQS}, 1.13 \mathrm{~g}$, Triton X-100, 0.5 gram without the clearing factors were incubated at room temperature for $2 \mathrm{~min}$. The absorbance was measured at $650 \mathrm{~nm}$ against a blank [32].

\section{${ }^{1} \mathrm{H}$ NMR Spectra confirms the masking effect of OA on Apo $\alpha$-LA by titration method}

The spectra of ${ }^{1} \mathrm{H}$ NMR were recorded using a Bruker spectrometer at $900 \mathrm{MHz}$ in $\mathrm{D}_{2} \mathrm{O}$. Lyophilized HALOA complex, native, and Apo a-LA $(2.5 \mathrm{mg})$ was dissolved in $100 \mu \mathrm{L}$ of $\mathrm{D}_{2} \mathrm{O}$, and the $\mathrm{pH}$ was maintained at $7.0 \mathrm{using} \mathrm{NaOD}$. Oleic acid $(4 \mathrm{mg})$ was dissolved in $75 \mu \mathrm{L}$ ethanol, and $10 \mu \mathrm{L}$ were added to $250 \mu \mathrm{L} \mathrm{D}_{2} \mathrm{O}$. Apo a-LA for ${ }^{1} \mathrm{H}$ NMR was generated by dissolving a-LA in double-distilled water (deuterated) containing 10-fold molar excess of EDTA at pH 8.0. All the spectra were recorded at $900 \mathrm{MHz}$.

\section{Transmission electron microscope (TEM) for the confirmation of HALOA like SNARE's}

A small drop of HALOA complex (usually about $4 \mu \mathrm{L}$ ) was pipetted onto a formvar-coated copper grid and allowed to dry at room temperature. Complex analysis was performed under FEI Tecnai G2 spirit twin transmission electron microscope equipped with Gatan digital GCD camera (Netherland) at $80 \mathrm{KV}$.

\section{Cell culture}

Cells (NIH and K562 cell line) were maintained in a culture medium composed of RPMI-1640, fetal bovine serum (5\%), antimycotic, and antibacterial $(0.1 \%$ ) in $50 \mathrm{~mL}$ of stock solution. Cell viability was checked by MTT assay (cells were inoculated at 5,000 cells/well on 96-well plates and incubated for 24 to 72 hours before the HALOA complex treatment). We continued cell treatments with HALOA complex (1 mg/mL, $0.5 \mathrm{mg} / \mathrm{mL}, 0.25 \mathrm{mg} / \mathrm{mL}, 0.125 \mathrm{mg} / \mathrm{mL})$, Apo a-LA (1 mg/mL), and OA (1 mg/mL) for 24 hrs. to $72 \mathrm{hrs} .20 \mu \mathrm{L}$ aliquot of 3-(4, 5-Dimethylthiazol-2-yl)-2,5 diphenyltetraoliumbromide (MTT, a yellow tetrazole; in PBS) was added to the wells, then incubated in $\mathrm{CO}_{2}$ incubator for two hours at $37^{\circ} \mathrm{C}$. After removing the supernatant carefully, $200 \mu \mathrm{L}$ of DMSO was added and mixed, and the absorbance was recorded at $563 \mathrm{~nm}$.

\section{DNA damaging detected during the treatment by HALOA complex}

DNA fragmentation was detected using agarose gel electrophoresis as per manufacturer guidelines. The cell suspension remaining after Trypan blue $\left(970 \mu \mathrm{L}, 2 \times 10^{6} / \mathrm{mL}\right)$ was lysed in $5 \mathrm{mM}$ Tris, $20 \mathrm{mM}$ EDTA, $0.5 \%$ Triton X-100 (pH 8.0) at $4^{\circ} \mathrm{C}$ for 1 hour and centrifuged at 13,000 rpm for $15 \mathrm{~min}$. DNA was precipitated in ethanol overnight at $-20^{\circ} \mathrm{C}$ and further treated with proteinase $\mathrm{K}$ and RNAse. Furthermore, we loaded $1.0 \%$ agarose gels into the electrophoresis unit, applying a constant voltage of $70 \mathrm{~V}$ for 2 hours. DNA fragments were visualized with ethidium bromide using the Bio-Rad gel doc.

\section{Table 1. Operating conditions for ICP-OES.}

\begin{tabular}{|l|c|c|}
\hline No. & Instrumental Conditions & Value \\
\hline 1. & Plasma Gas Flow (L/min) & 8 \\
\hline 2. & Auxiliary Gas Flow (L/min) & 0.2 \\
\hline 3. & Carrier Gas Flow (L/min) & 0.55 \\
\hline 4. & RF Power (W) & 1300 \\
\hline 5. & Plasma View & Axial \\
\hline 6. & Sample Flow Rate (ml/min) & 1.0 \\
\hline
\end{tabular}




\section{JOURNAL of MEDICINE and LIFE}

\section{Apoptosis by Annexin V-FITC assay}

For apoptosis analysis, cells were seeded in 6 -well plates at a density of $2.0 \times 10^{5}$ cells/well and allowed to grow overnight. The next day, the cells were treated with HALOA $(0.5 \mathrm{mg} / \mathrm{mL})$ for $24 \mathrm{~h}$ at $37^{\circ} \mathrm{C}$. Untreated cells were used as control. After incubation, the cells were harvested and washed twice with cold PBS. Next, $1 \times 10^{5}$ cells were dispersed in $100 \mu \mathrm{L}$ of $1 \times$ Annexin V binding buffer. Subsequently, $5 \mu \mathrm{L}$ of Annexin V- FITC and $5 \mu \mathrm{L}$ of PI and PE Texas red were added, and cells were incubated at room temperature in the dark for 15 min. Finally, $400 \mu \mathrm{L}$ of $1 \times$ Annexin $\mathrm{V}$ binding buffer was added under gentle mixing, and the samples were analyzed using flow cytometry (BD Biosciences, San Jose, CA) and FlowJo software.

\section{Cell proliferation by EdU assay}

Cell proliferation and DNA synthesis were determined using a Click-iT® EdUiFluor ${ }^{\circledR} 488$ Assay Kit (ab2 19801) according to the manufacturer's protocol regarding FACS and fluorescence microscopy.

\section{Apoptosis Markers Assay}

ELISA was used to check the expression level of survivin (ab1 19607- Survivin Human ELISA Kit) and IL8 (Ray Bio® Human IL-8 ELISA Kit) in cell lysate. The colorimetric assay was used to confirm the total antioxidant (TAC) of cells after treatment with HALOA complex using an antioxidant assay kit (Sigma Aldrich- Catalog Number CS0790), following the manufacturer's protocol. Bioinformatics tools used for docking were Swiss dock and Pydock.

\section{Statistical analysis}

All the data were expressed as mean \pm standard deviation (SD). The results were analyzed using SPSS 21.0 version and Graph pad software (Prism 5). The significance of differences was analyzed using one-way ANOVA and Student's t-test $(* \mathrm{p}<0.05)$.

\section{RESULTS}

We used Human alpha-lactalbumin as starting material, converted it into the HALOA complex, and then validated its anti-tumor activity on the K562 cell line and NIH (normal cell line).

\section{In-silico study reveals the interaction of apo $\alpha$-LA with OA}

Formulation of the HALOA complex was done by removing calcium ions from human a-LA (Figure $1 \mathrm{a}$, b). Furthermore, docking was performed with oleic acid using Swiss dock tools, as shown in Figure $1 \mathrm{c}$. We found 46 clusters with different binding energy efficiency. The result indicated that oleic acid resides around apo a-LA but is not found in the pocket of calcium ion (the free energy table is attached as supplementary data).

\section{Formation and structural characterization of HALOA Complex}

The UV absorbance spectrum was recorded to compare the structure of the native and apo forms of a-LA at room temperature. We found that apo a-LA isolated by gel filtration is not similar to the native form of LA shown in Figure $2 \mathrm{a}^{-} \mathrm{c}$. The CD data were analyzed using BEST SEL web service tools, and we observed that the structure of native LA contains the majority of turns. Simultaneously, the HALOA complex constitutes $17.3 \%$ anti-parallel beta-sheet and $82.7 \%$ turn (data attached in a supplementary form). HALOA complex and LA (apo and native) show an increase in CD amplitude around the 200-230 nm region. The trajectory of CD spectra of native LA and complex are the same. The near UV-CD region demonstrates that both the complex and the LA show a marked reduction in negative ellipticity around the 260-300 nm wavelength region. There is a peculiar loss in signal trajectory around tyrosine and tryptophan regions, as shown in Figure 2 c. Overall, these observations indicate an alteration in the globular structure from the native state to the formulated HALOA complex, as shown in Figure 2.

The exposed hydrophobic amino acid cluster of protein was widely detected through binding with fluorescent probe ANS, which significantly increases fluorescence intensity at emission wavelengths from 510 to $480 \mathrm{~nm}$. Native LA failed to bind ANS because of the unavailability of hydrophobic parts, as shown in Figure $2 \mathrm{~d}$, with low fluorescence intensity at $510 \mathrm{~nm}$. In contrast, the apo a-LA showed enhanced intensity at wavelength $477 \mathrm{~nm}$, whereas the HALOA complex showed maximum fluorescence at $488 \mathrm{~nm}$ due to the absence of $\mathrm{Ca}^{2+}$ ions. Consequently, we can say that the apo a-LA and HALOA complex have a high affinity to bind with ANS dye than the native form of a-LA because of the availability of hydrophobic patches. We have observed a hypsochromic shift in the graph towards a lower wavelength. The masking effect of OA was validated by SDS-PAGE, and we observed that LA integrity did not alter 


\section{JOURNAL of MEDICINE and LIFE}

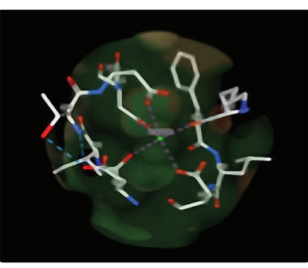

[CA]124:A

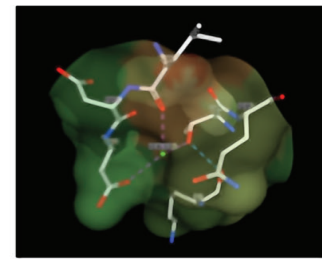

[CA]125:A

Human $\alpha$-LA with $\mathrm{Ca}^{2+}$

a.

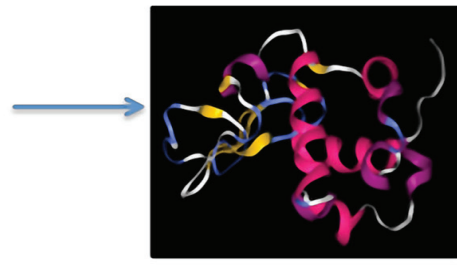

a-LA without $\mathrm{Ca}^{2+}$ (1A4V)

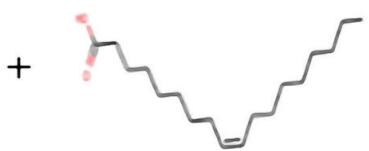

Oleic acid (ZINC6845860)

\section{Docking Result}

(Swiss Dock)

c.
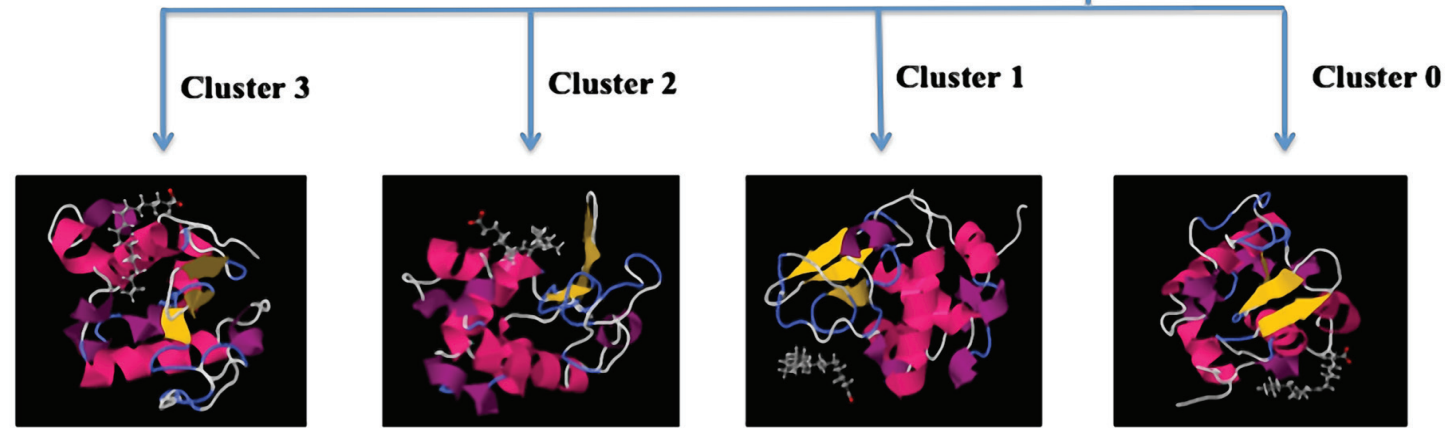

Figure 1. Interaction of oleate with Human $\alpha$-LA. (a, b) Removal of calcium ions from human a-LA leads to formulation of HALOA complex. (c) Furthermore, docking was performed with oleate by using Swiss dock tools.

lanes C, D, E, G (Figure 2 e). There was no band found in complex lane F. This result indicates the aggregation behavior of oleic acid around apo a-LA, which was further validated and confirmed by NMR and TEM techniques. ICP-OES and Arsenazo-III confirmed removing calcium ions (Figure $2 \mathrm{f}$ ); figure $2 \mathrm{~g}$ is showing that the concentration of calcium ion $0.018 \mathrm{mg} / \mathrm{L}$ is negligible in an account of standard Whey Protein and Native alpha-lactalbumin, while Arsenazo-III dye binds with available calcium ion in the solution of unfolded protein.

\section{NMR and TEM confirm the HALOA complex attains a structure as SNARE's}

The spectra of ${ }^{1} \mathrm{H}$ NMR $(900 \mathrm{MHz})$ signal of native a-LA shows characteristics of a proper folded globular structure indicated by narrow lines and a significant shift in the dispersion of many strong signals seen around the aromatic region (around $7 \mathrm{ppm}$ ), with a frequent shift in methyl signal (between 0-1 ppm) as shown in Figure 3 a. However, the NMR spectral pattern of the apo form of LA was different in Figure 3 b, c, compared to the native form. The NMR signals of apo were significantly reduced, suggesting that the protein could attain the apostate in the absence of $\mathrm{Ca}^{2+}$. The NMR signals of apo a-LA significantly decreased upon titration with OA, suggesting a strong interaction between apo a-LA and OA (Figure $3 \mathrm{~d}$, e). We found that by increasing the volume of $\mathrm{OA}(6 \mu \mathrm{L}, 12 \mu \mathrm{L}$, and $18 \mu \mathrm{L}$ ), there is a decrease in the intensity of NMR signals.

The TEM result confirmed that the encapsulation of apo a-LA within OA forms a product similar to SNARE's complex. Previous literature indicates that $\mathrm{OA}$ could attain the structure of micelles at $\mathrm{pH}$ more than 10.5, and micelles (single layered) further form plasma membrane like vesicles (double layered) if the $\mathrm{pH}$ is decreased below 9.0 [33-35]. Turbidity measurements demonstrate surface hydrophobicity by increasing the concentration of $\mathrm{OA}$ in an aqueous solution of apo a-LA at different wavelengths, as shown in Figure $3 \mathrm{f}-\mathrm{h}$. The result shown in Figure $3 \mathrm{i}-1$ reveals that the overall size of complex formed by adding OA with apo a-LA is within the range of $500 \mathrm{~nm}$, like SNARE's complex (Figure 3). Therefore, SNARE's like behavior of the formulated complex is analogous to similar effects elucidated when proteins like tau [36], alpha-synuclein [37] were added in solutions of fatty acid or an anionic detergent.

\section{Cell culture and cell viability assay}

NIH (normal cell line for toxicity check of complex) and K562 cell lines (chronic myeloid leukemia) were treated with LA (Apo a-LA; 1 $\mathrm{mg} / \mathrm{mL})$, OA $(1 \mathrm{mg} / \mathrm{mL})$, and HALOA complex $(1 \mathrm{mg} / \mathrm{mL}, 0.5 \mathrm{mg} / \mathrm{mL}, 0.25 \mathrm{mg} / \mathrm{mL}, 0.125 \mathrm{mg} / \mathrm{mL})$. Cell viability was determined 


\section{JOURNAL of MEDICINE and LIFE}

a.

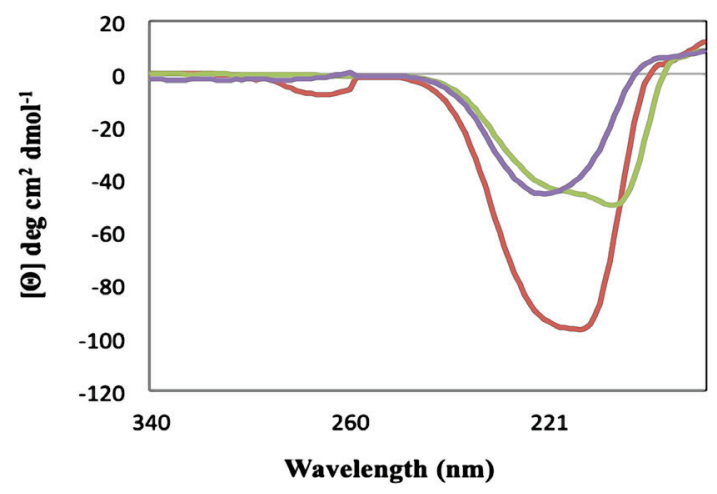

b.

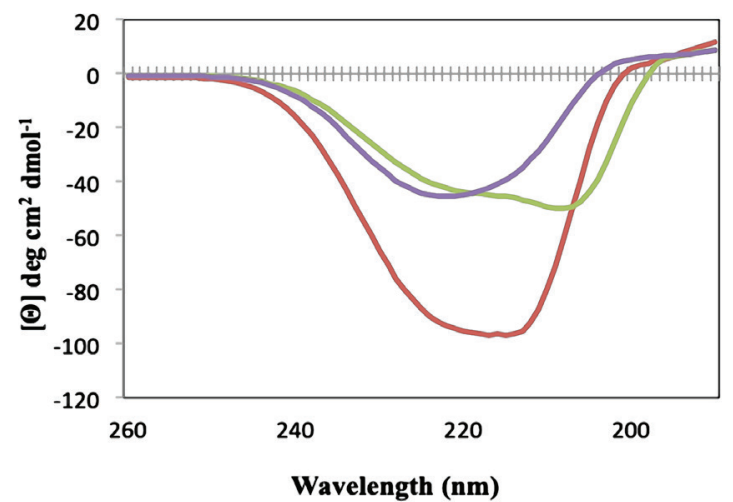

Wavelength (nm)

LA

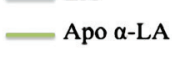

HALOA

c.

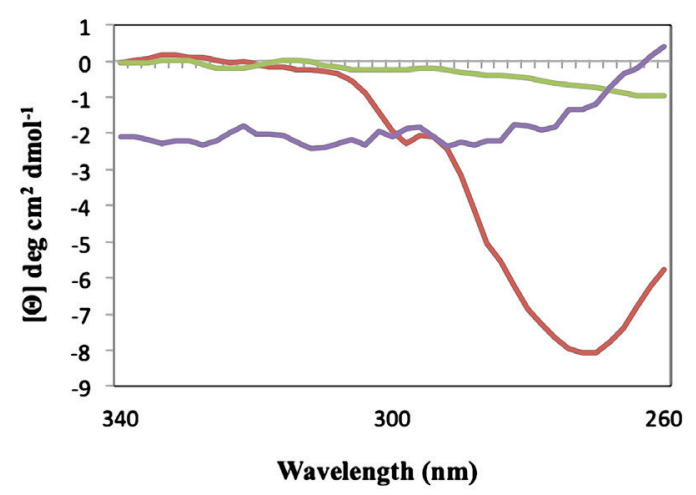

LA

Apo $\alpha$-LA

HALOA

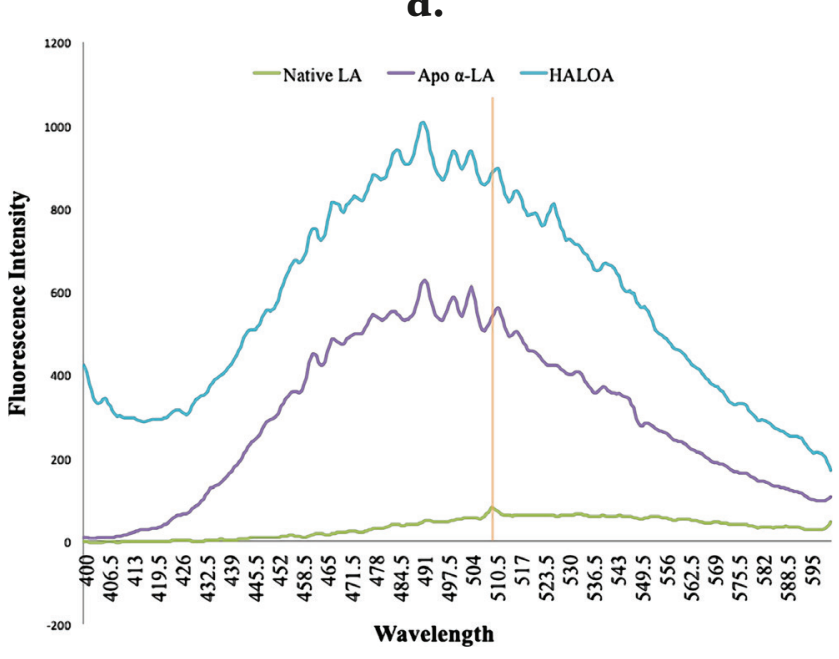

Figure 2. HALOA complex validation; (a) combined graph of Near and Far UV-CD spectra, red color shows Human lactalbumin (LA) which contain turns, the green color shows the Apo $\alpha$-LA, whereas, the violet indicates the HALOA complex consisting of a beta-sheet and turns. $(b, c)$ far (190-260 nm) and near (260-340 nm) UV-CD Spectra shows a loss in the native structure of $\alpha$-LA during the conversion into HALOA. (d) ANS fluorescence spectra of Native LA (green color), Apo $\alpha$-LA (violet color), and HALOA (sky blue) show the hypsochromic shift towards the lower wavelength. (e) SDS-PAGE result in which lane C, G shows native alpha-lactalbumin with calcium ion; lane D, E shows without calcium ion, lane F for complex but no band found in this lane because of masking effect of oleic acid on Apo $\alpha$-LA, lane A for protein ladder and B shows BSA. (f) ICP result used to determine the calcium ion concentration. The concentration of calcium ion was found to be high in native human $\alpha$-LA compared to EDTA treated LA, and the result of the complex, with and without EDTA, shows the value around the blank (no calcium ion). (g) Arsenazo III binds with the calcium ion; its absorbance is highest in the native protein compared to EDTA, treated protein, and complex form of protein. In contrast, the result was approximate as a negative control, which indicated that the complex does not have calcium ions.

at 24, 48, and 72 hrs. after treatment with formulated candidates by MTT reagent, following the manufacturer's protocol. From this result, we calculated the $\mathrm{IC}_{50}$ which indicates that $0.5 \mathrm{mg} / \mathrm{ml}$ of HALOA complex shows the best result without any cell cytotoxicity as shown in Figure 4. The $\mathrm{IC}_{50}$ value is the most effective at a concentration of $0.5 \mathrm{mg} / \mathrm{mL}$, which was further used throughout this study.

\section{Biological activity of HALOA complex and its effect on molecular markers (TAC, IL-8, and Survivin)}

The HALOA complex $(0.5 \mathrm{mg} / \mathrm{mL})$, Apo a-LA $(1 \mathrm{mg} / \mathrm{mL})$, and $\mathrm{OA}(1 \mathrm{mg} / \mathrm{mL})$ significantly reduced cell viability in 24 hours. DNA fragmentation was observed 8 hours after the HALOA complex treated K562 cells, but no DNA fragmentation was found in NIH cells, as shown in Figure 5 a. To determine whether the growth inhibition of HALOA complex $(0.5 \mathrm{mg} / \mathrm{mL})$ in K562 cells was associated with programmed cell death, apoptosis rate was evaluated using AnnexinV-FITC staining. K562 cells were evaluated before and after treatment with HALOA complex by flow cytometry within 24 hours, showing the death index rate by $57.1 \%$. Result obtained from FACS was analyzed using FlowJo software. Quadrant Q1 showed necrotic cells, Q2 late apoptotic cells, Q3 early apoptotic cells, and Q4 


\section{JOURNAL of MEDICINE and LIFE}

e.

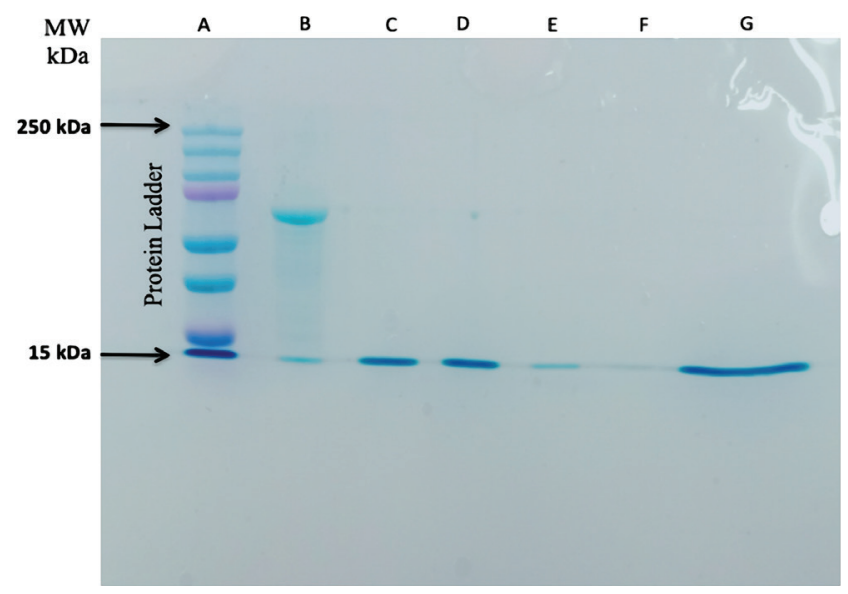

f.

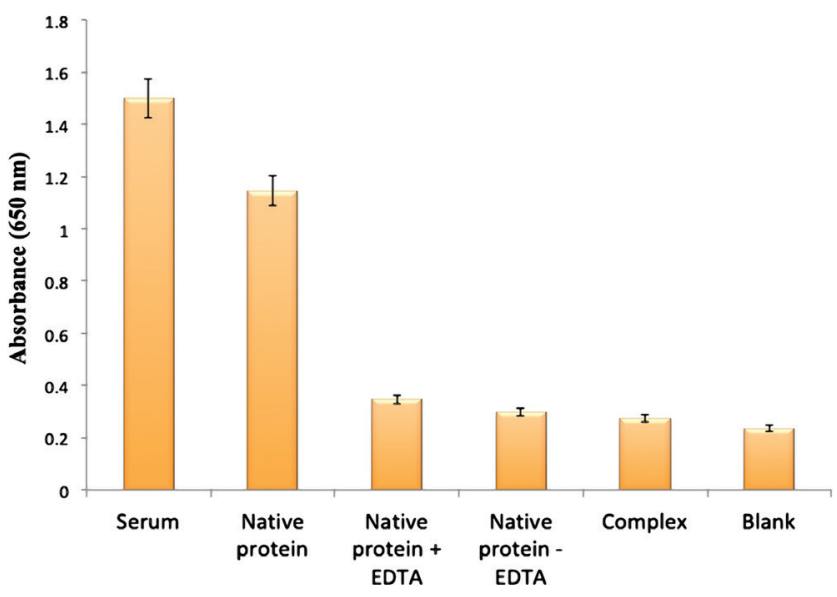

g.

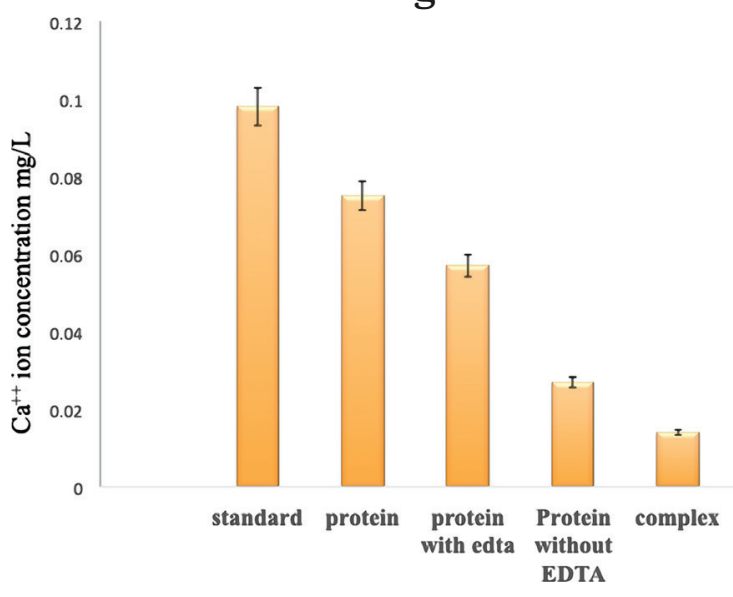

Figure 2. Continued.

showed live cells (Figure $5 \mathrm{~b}-\mathrm{d}$ ). The result was obtained using a t-test with a p-value of 0.012 . K562 cells were grown to $80-90 \%$ confluence in 6 well plates and analyzed by FACS and fluorescence microscope. After the treatment with HALOA complex $(0.5 \mathrm{mg} / \mathrm{mL})$, we explored the DNA content of K562 cells during the cell cycle progression using EdU. We found that the complex inhibits maximum growth in the G2/M phase of K562 cells, reducing cell proliferation rate by $73.20 \%$ and fold change of 16.4 (Figure 5 e-m). Under the fluorescence microscope, there is a significant reduction in fluorescence intensity within $72 \mathrm{hrs}$.

HALOA complex increases total antioxidant level in the K562 cell line $(0.113 \pm 0.013 \mathrm{mM}$, p-value; 0.006) as shown in Figure 6 a. Survivin was reported as a gatekeeper at the G2/M phase boundary of cell cycles [38]. The expression of survivin was found to be very high in K562 cells $(2990 \pm 43.13 \mathrm{pg} / \mathrm{mL})$, but after treatment with OA, Apo a-LA and complex $(2666 \pm 45.25 \mathrm{pg} / \mathrm{mL}, \mathrm{p}$-value; 0.003), (LA; $2573 \pm 67.88 \mathrm{pg} / \mathrm{mL}$, p-value; 0.027), (2346 $\pm 1.12 \mathrm{pg} / \mathrm{mL}$, p-value; 0.006) its expression significantly decreased (Figure 6 b). Moreover, we examined the expression level of IL8 and total antioxidant (TAC) and found that the complex significantly reduces IL-8 level $(43.83 \pm 2.75 \mathrm{pg} / \mathrm{mL}$, p-value; 0.05) as shown in Figure $6 \mathrm{c}$. The maximum reduction was found in a case of complex treated cells, which might indicate that the complex can target survivin. This result was further validated by the docking (Pydock) method, which indicates that HALOA (red color) has a high affinity to bind at a phosphorylated site (at 34) of survivin (white and blue color), as shown in model 1 (Figure $6 \mathrm{~d}$ ). We got a total of 10 docking models (from the Pydock server) with different energy scores allowed, as shown in Figure 6 d. All values are presented in Table 2.

\section{DISCUSSION}

Human a-LA can vary its biological function according to its conformational state. Fatty acid (oleic acid C18:1) acts as a cofactor for the protein-lipid complex. Our finding agrees with other studies that explore the formation of a new variant (HALOA complex) by altering the conformational state of alpha-lactalbumin from native to apo state, followed by a mixture with oleic acid. Our result showed that 
JOURNAL of MEDICINE and LIFE

a.

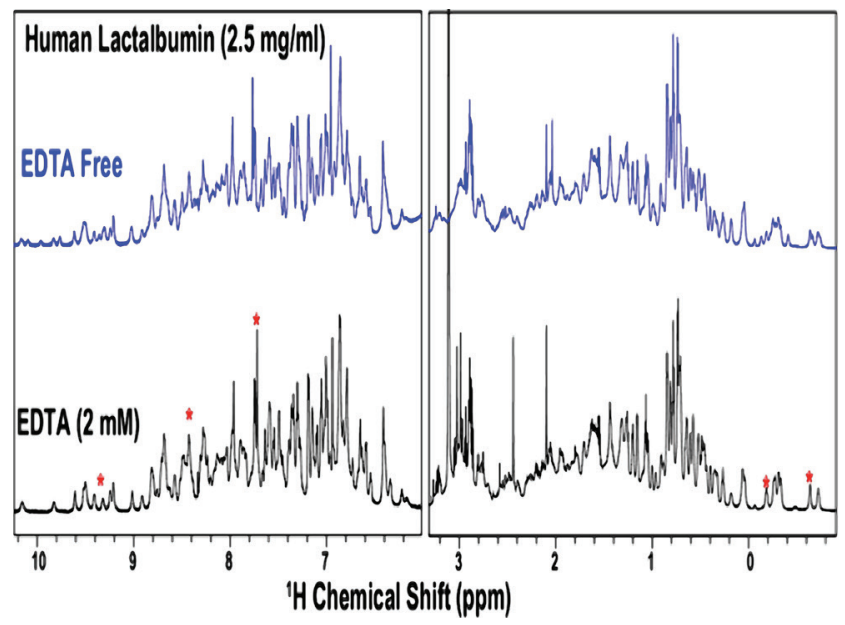

c.

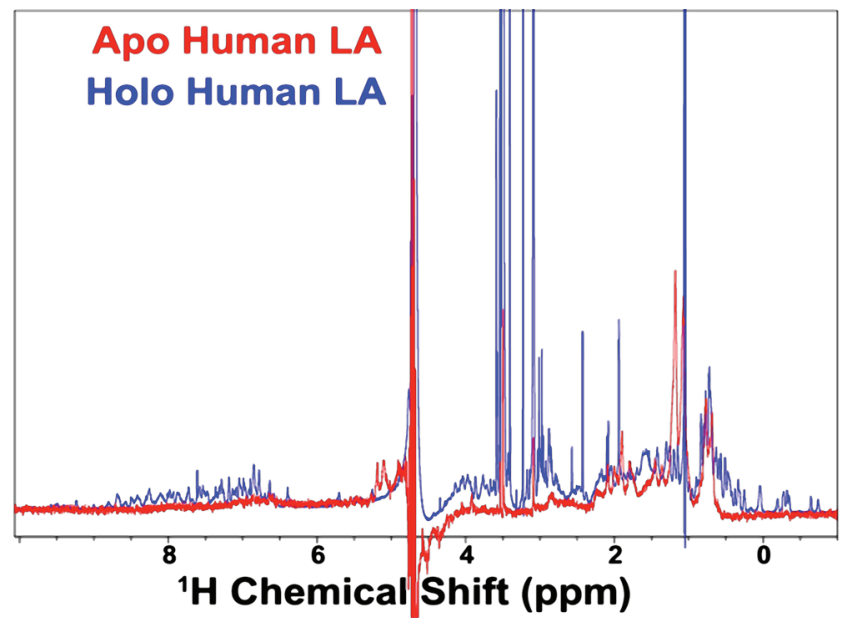

e.

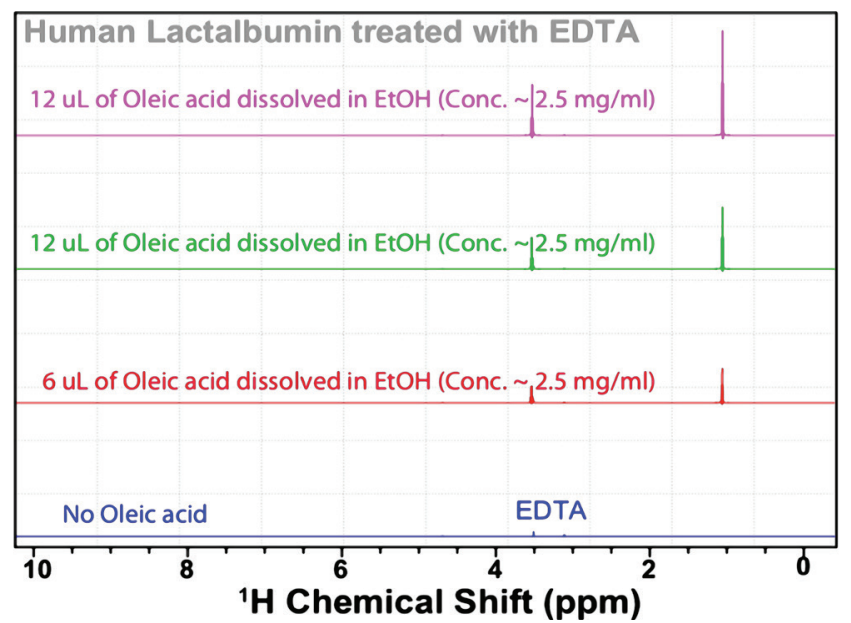

b.

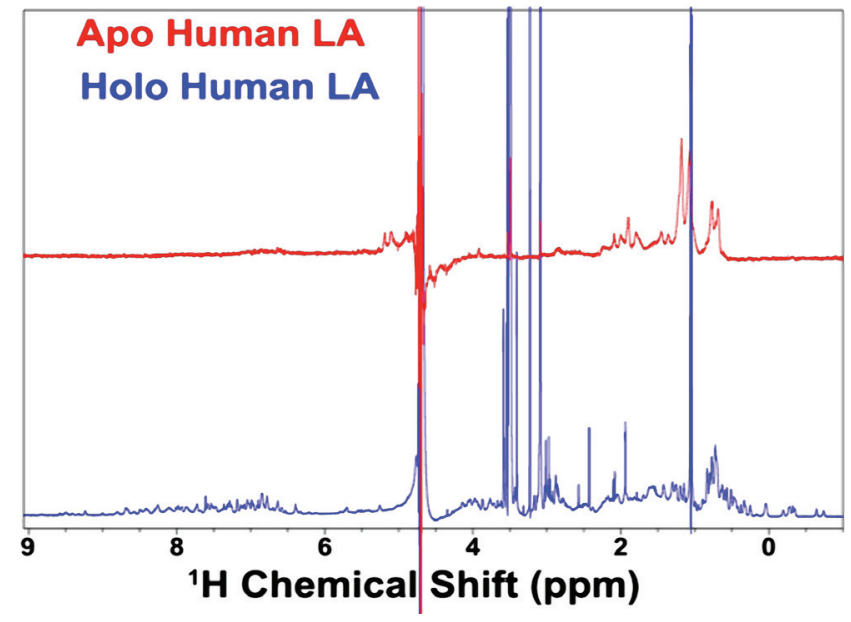

d.

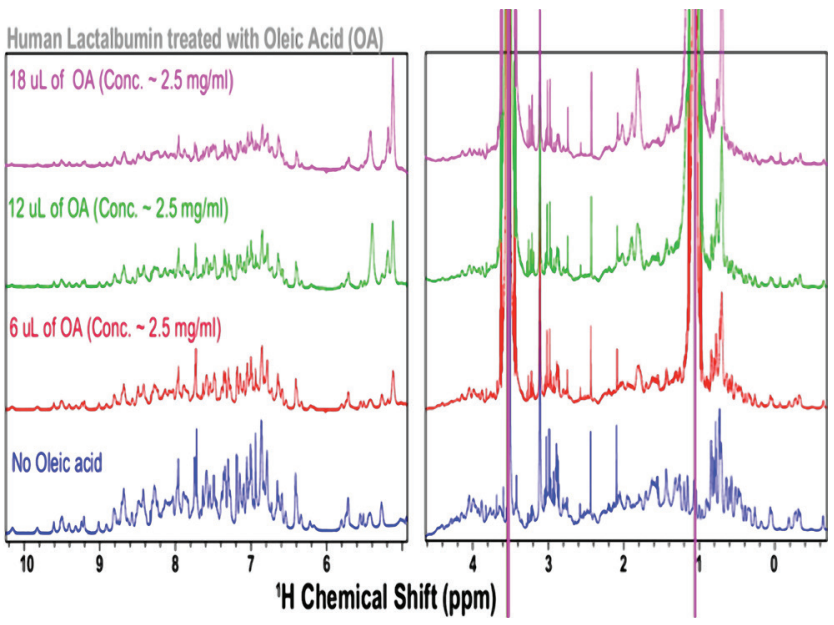

f.

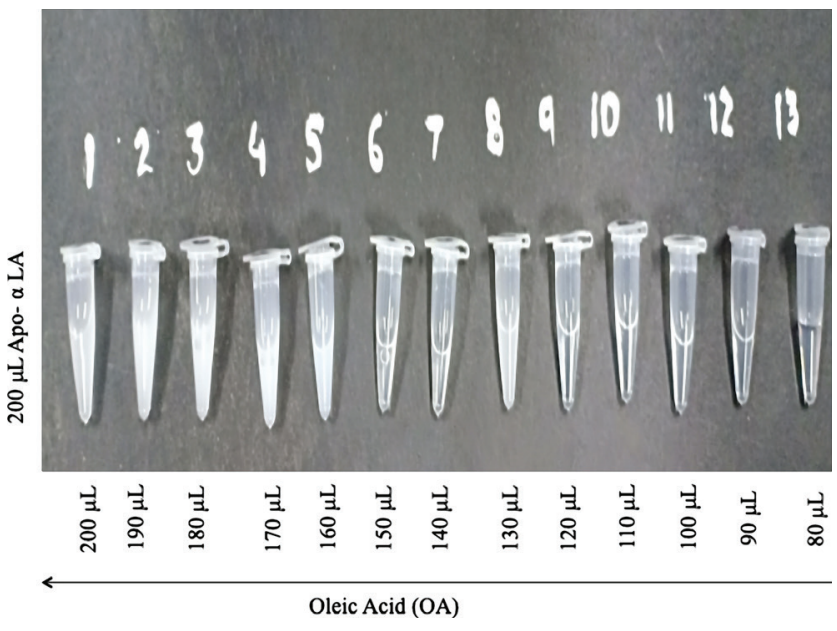

Figure 3. HALOA complex attains the similarity with SNARE's complex; (a) $2.5 \mathrm{mg}$ of native LA was dissolved in DPBS. We recorded the spectra at $900 \mathrm{MHz}$ and, when added to EDTA $(2 \mathrm{mM})$, we found the loss of Apo $\alpha$-LA in spectra, marked with a red asterisk. (b, c) NMR spectral pattern of apo and holo (native LA) forms of human $\alpha$-LA was different. Compared to the holo form, the NMR signals of the apo form of Human LA are significantly reduced, suggesting that the protein is possibly forming the apostate in the absence of $\mathrm{Ca}^{2+}$ ions. (d, e) NMR signals of apo $\alpha$-LA progressively decrease upon titration with Oleic acid, suggesting a strong interaction between protein and oleic acid. The decreased intensity of the NMR signal upon the addition of oleic acid suggested that the HALOA complex is not contributing to the ${ }^{1} \mathrm{H}$ NMR signal. Characterization of changes in aggregation state OA after the addition of Apo $\alpha$-LA. (f, $g$ ) turbidity measurement and absorbance of this titration taken from $200-900 \mathrm{~nm}$ wavelength. (h) Turbiditimetric analysis; Addition of OA solutions (200 $\mu \mathrm{L}-100 \mu \mathrm{L})$ in Apo $\alpha$-LA ( $200 \mu \mathrm{L})$. The absorbance of solutions was recorded at $400 \mathrm{~nm}$. (i-I) size of HALOA complex measured by TEM in bright and darkfield, which shows a $500 \mathrm{~nm}$ range of size that is the exact size of t-SNARE's complex. 


\section{JOURNAL of MEDICINE and LIFE}

g.

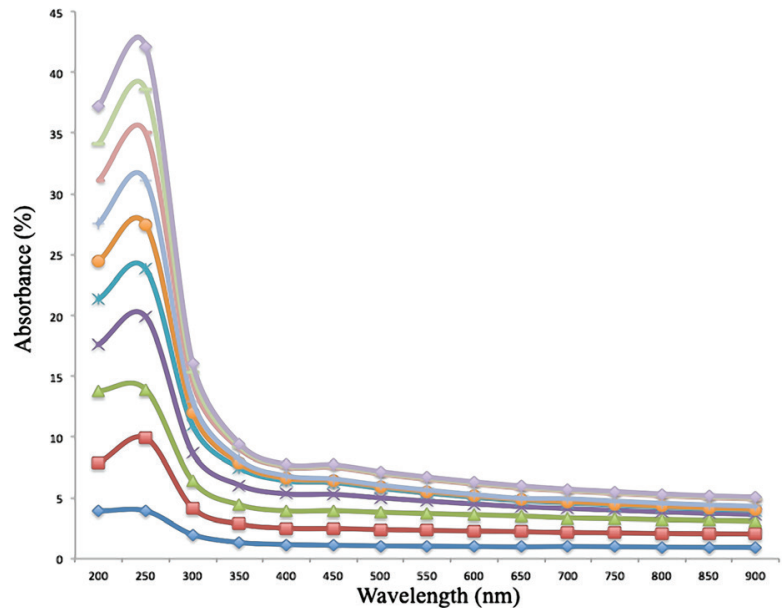

i.

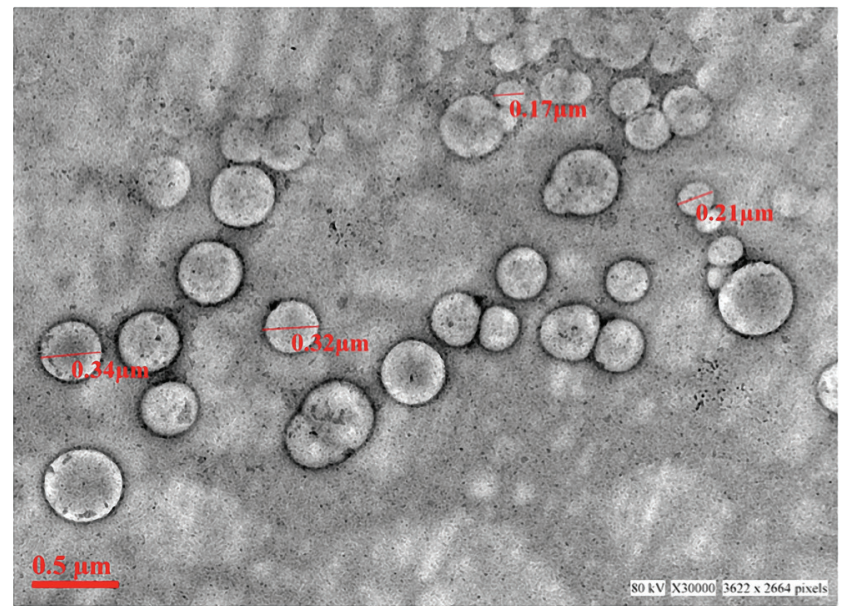

k.

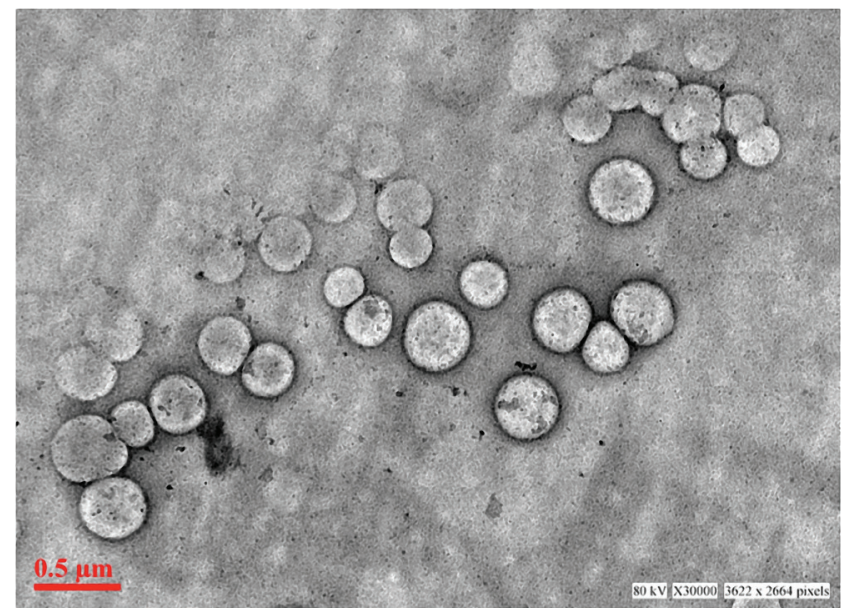

h.

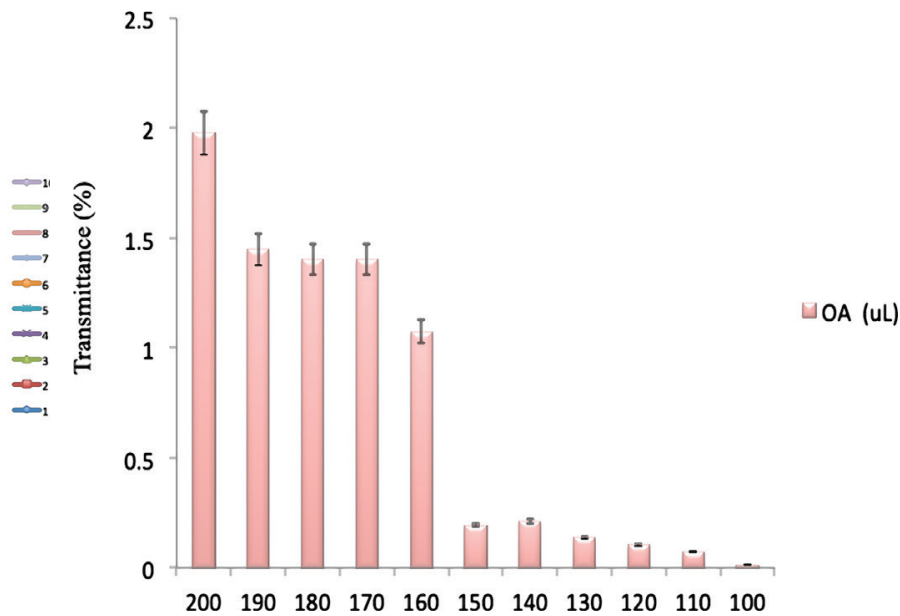

j.

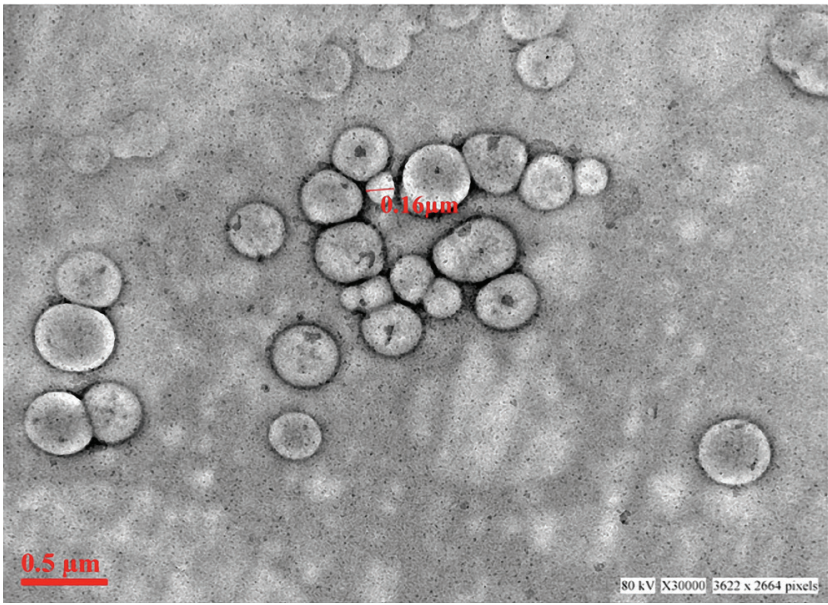

1.

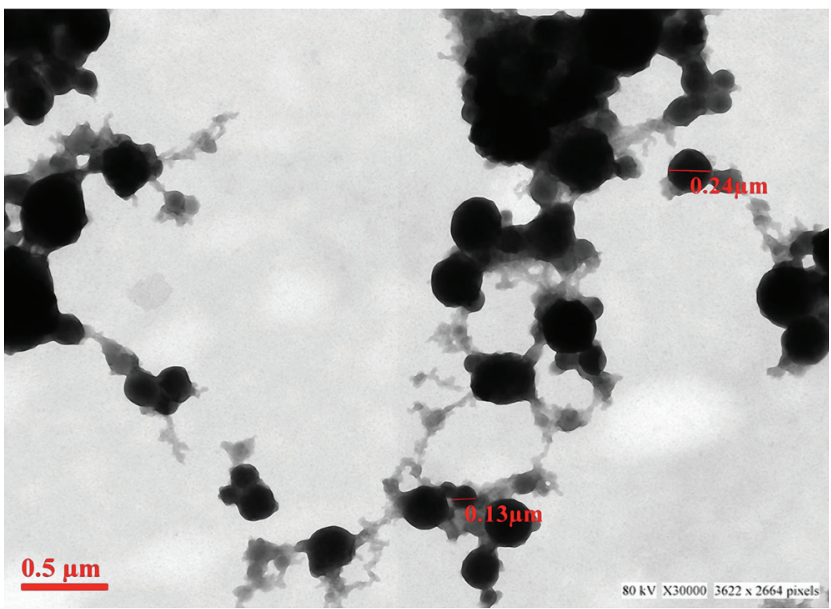

Figure 3. Continued.

the formed HALOA complex resembles SNARE behavior. EDTA was used to help release calcium ions and induce the unfolding in native a-LA, confirmed by spectroscopic techniques. The calcium ion removal helps accessing the hydrophobic patches in a-LA, which is probed by ANS dye. Moreover, the formulated HALOA complex increases fluorescence intensity and shifts signal towards a lower wavelength (blue shift) when juxtaposed with its native a-LA. The near UV-CD spectroscopy of native a-LA had maximum amplitude at $274 \mathrm{~nm}$ because of tyrosine residues and at $296 \mathrm{~nm}$ because of tryptophan amino acids. Still, there is a significant loss of signal in 
JOURNAL of MEDICINE and LIFE
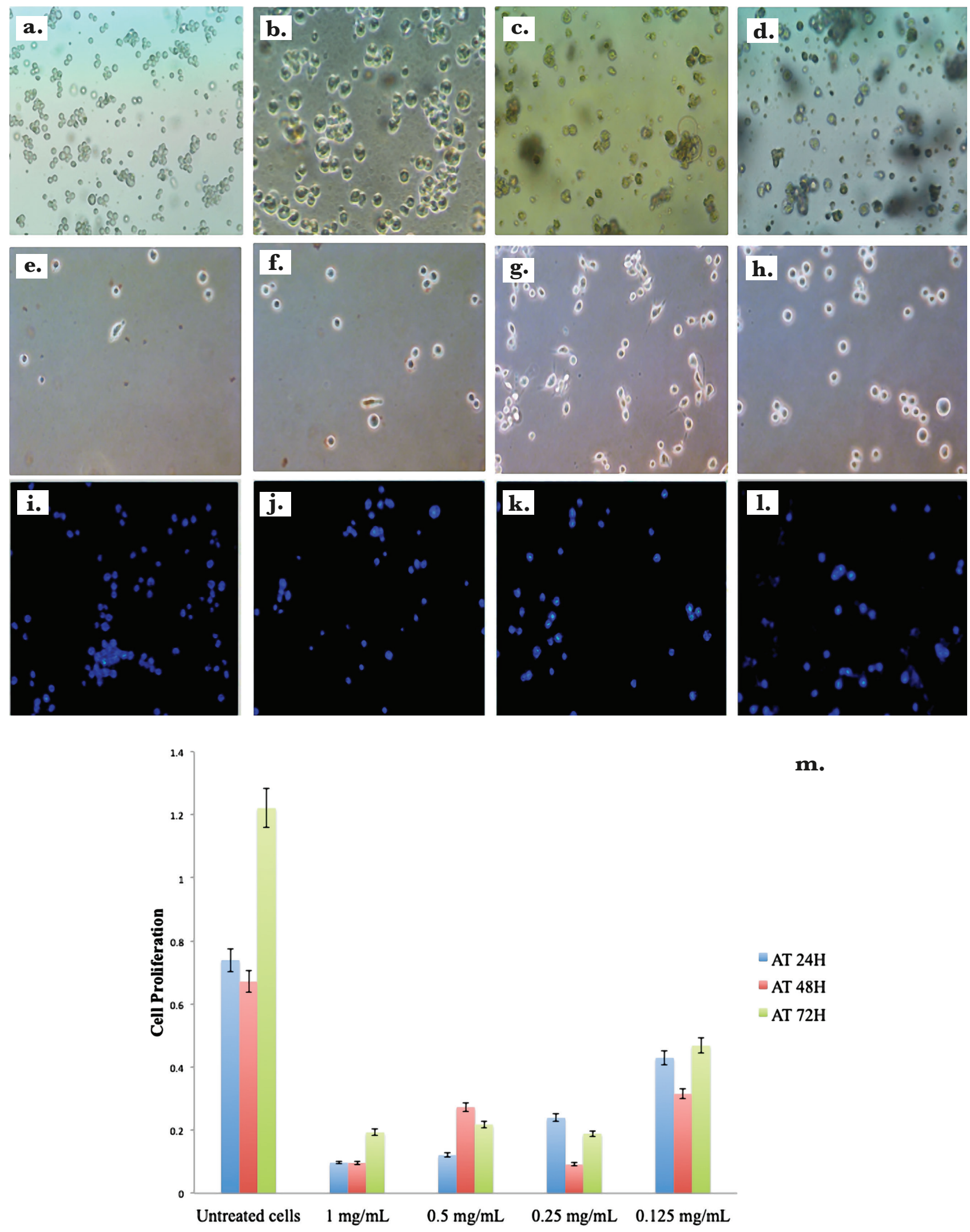

m.

Concentration $(\mathrm{mg} / \mathrm{mL})$ of HALOA complex

Figure 4. K562 Chronic myeloid leukemia cell lines, (b) Apo $\alpha$-LA (1 mg/ml) treated cells, (c) OA acid (1 mg/mL) treated cells show apoptosis in $\mathrm{K} 562$ cells (d-h) cells treated with different conc. of the HALOA complex (d. $2 \mathrm{mg} / \mathrm{mL}$, e. $1 \mathrm{mg} / \mathrm{mL}$, f. $0.5 \mathrm{mg} / \mathrm{mL}, \mathrm{g} .0 .25 \mathrm{mg} / \mathrm{mL}$, h. 0.125 $\mathrm{mg} / \mathrm{mL}$ ). (i-l) Hoechst-stained dye shows a low intensity using treatment with HALOA complex (i. K562 cells, j. $1 \mathrm{mg} / \mathrm{mL}$, k. $0.5 \mathrm{mg} / \mathrm{mL}$, I. $0.25 \mathrm{mg} / \mathrm{mL})$. $(\mathrm{m})$ cell viability assessed by MTT assay, from where we calculated the $\mathrm{IC}_{50}$ value by which we decided the dose of HALOA complex $(0.5 \mathrm{mg} / \mathrm{mL})$ that was further used for the study. 


\section{JOURNAL of MEDICINE and LIFE}

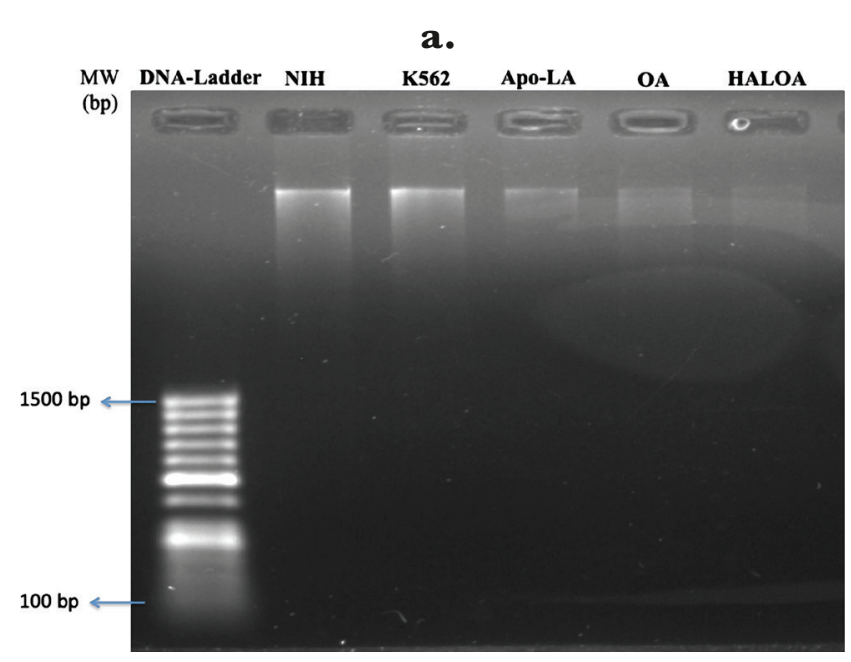

c.

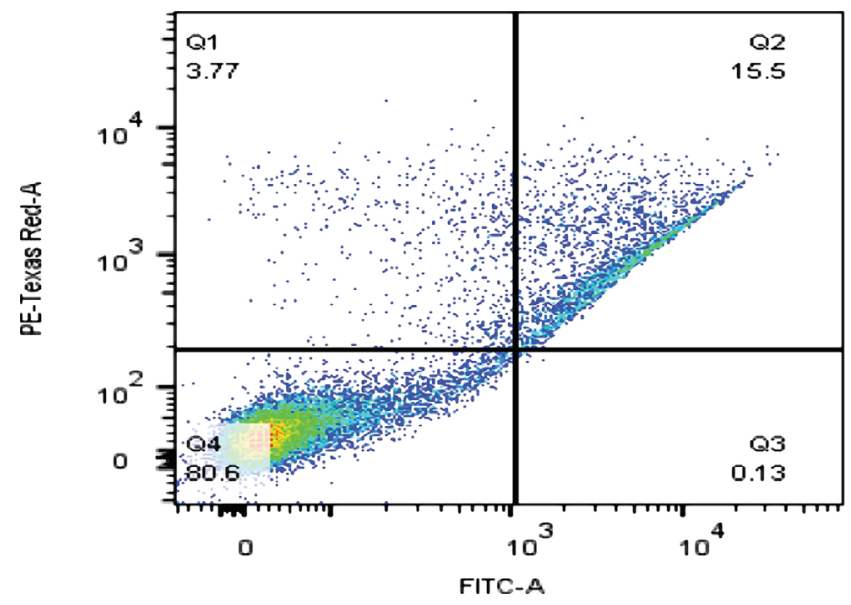

e.

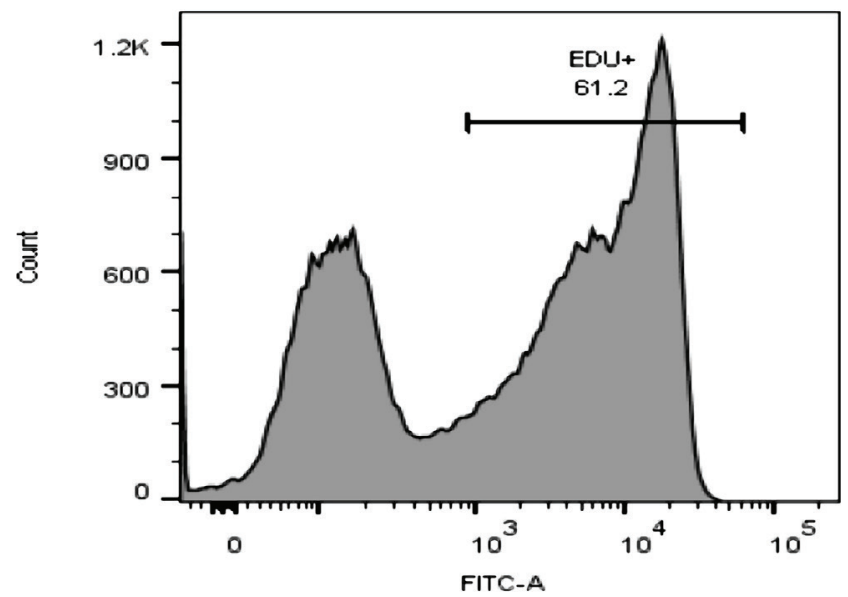

b.

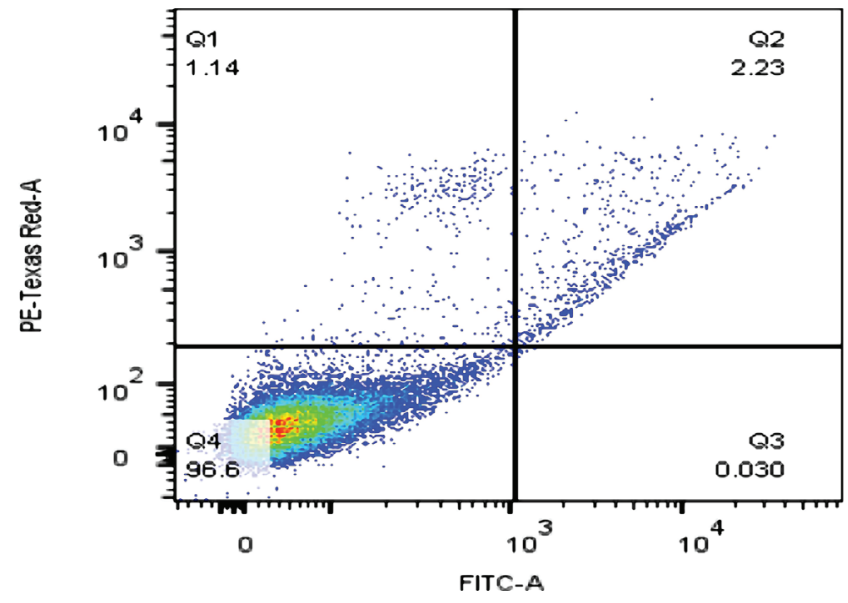

d.

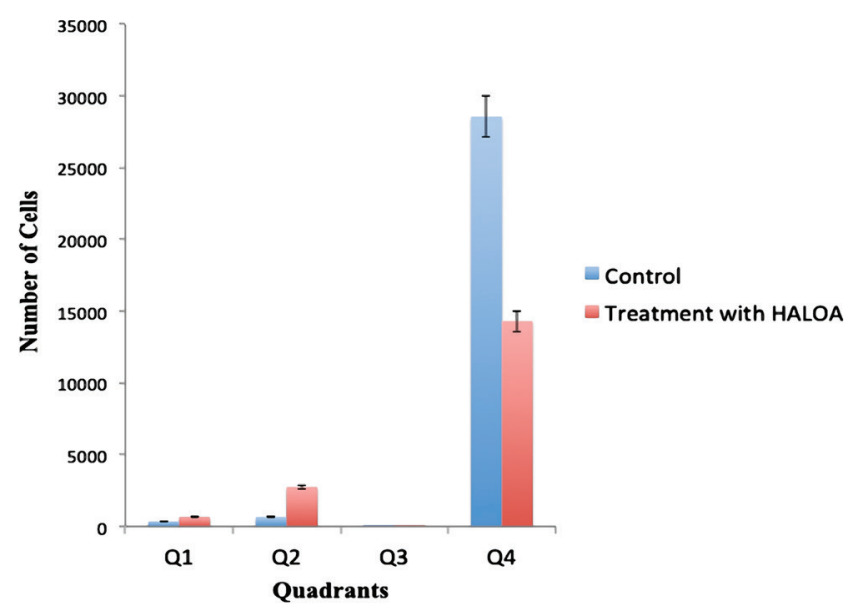

f.

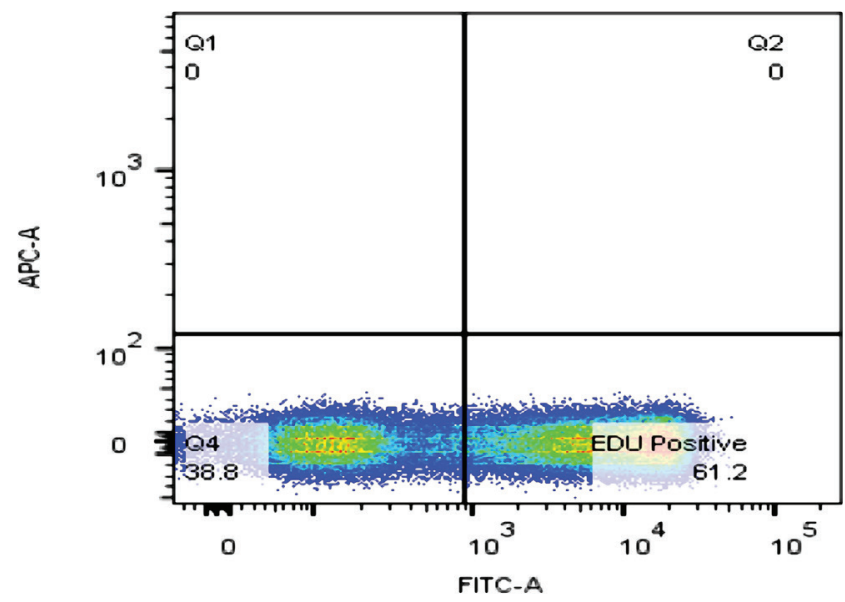

Figure 5. Complex leads apoptosis in K562 cells; (a) DNA fragmentation analyzed on normal cell line (NIH). In the first column, we found no DNA damage by HALOA complex $(0.5 \mathrm{mg} / \mathrm{mL})$ compared with DNA of $K 562$ cell line, but in HALOA $(0.5 \mathrm{mg} / \mathrm{mL})$, Apo $\alpha$-LA (1 mg/mL), and OA (1 mg/mL) the column found damaged DNA. (b-d) Phosphatidylserine externalization is a lead marker for apoptosis which was confirmed by FACS (Annexin V-FITC assay) (c) K562 cells as the control without treatment in which Q1- Necrotic cells, Q2- Late apoptotic, Q3- Early apoptotic cells, and Q4-live cells found statistically significant results with a p-value of 0.012 . This experiment was performed within $8 \mathrm{~h}$, which shows the significantly increase in no. of apoptotic cells by HALOA $(0.5 \mathrm{mg} / \mathrm{mL})$ complex as shown in (c). (d) bar diagram decreased in the cell in different quadrants with a p-value of 0.012 . Cell proliferation assay by EdU dye (e-m) shows a 16.4-fold decrease in the $\mathrm{G} 2 / \mathrm{M}$ population by the HALOA complex $(0.5 \mathrm{mg} / \mathrm{mL})$. (e-h) shows a reduction in cell proliferation rate $(73.20 \%)$ by the HALOA complex $(0.5 \mathrm{mg} / \mathrm{mL})$. (i-I) shows the fluorescence of EdU dye under a fluorescence microscope, which indicated that a decrease in the population of live cells (fig. i) after treatment with HALOA $(0.5 \mathrm{mg} / \mathrm{mL})(\mathrm{J})$, Apo $\alpha$-LA $(1 \mathrm{mg} / \mathrm{mL})(\mathrm{k})$, and OA $(1 \mathrm{mg} / \mathrm{mL})(\mathrm{I})$ shows a significant reduction in cells within $72 \mathrm{~h}$ and $(\mathrm{m})$ shows a reduction in cell population maximum in the $\mathrm{G} 2 / \mathrm{M}$ phase by the treatment with complex $(0.5 \mathrm{mg} / \mathrm{mL})$. 


\section{JOURNAL of MEDICINE and LIFE}

g.

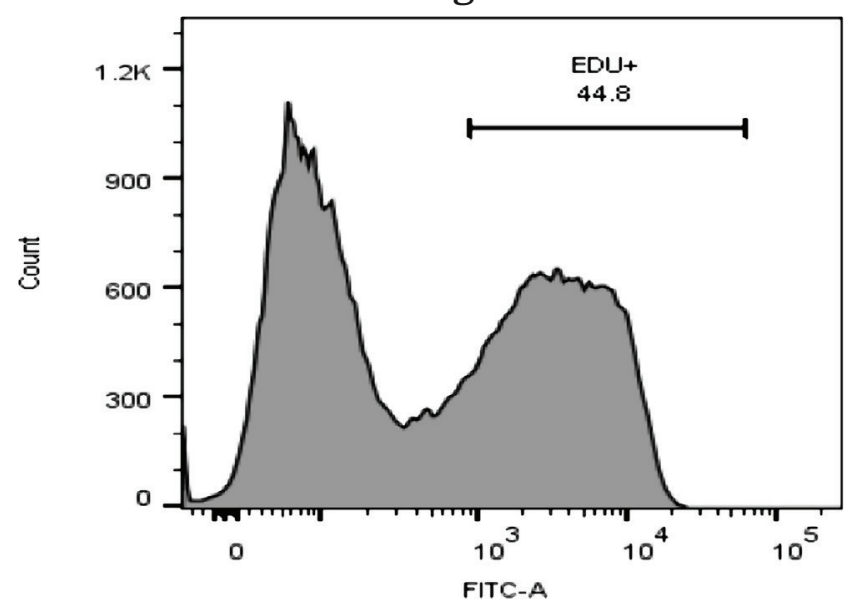

i.

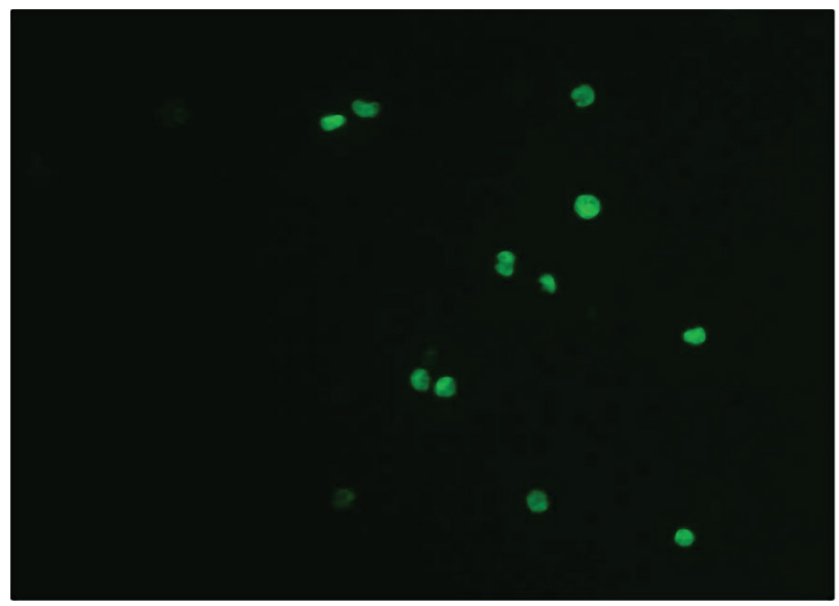

k.

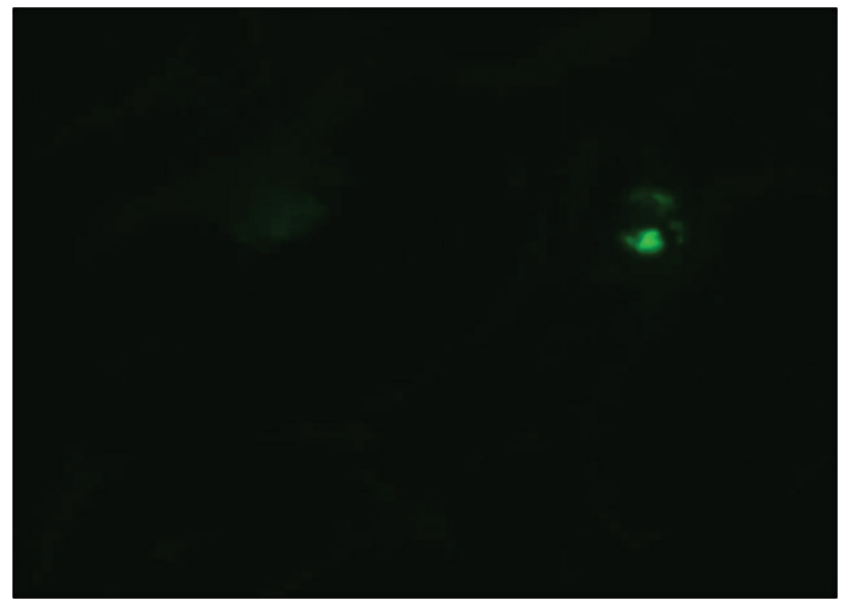

h.

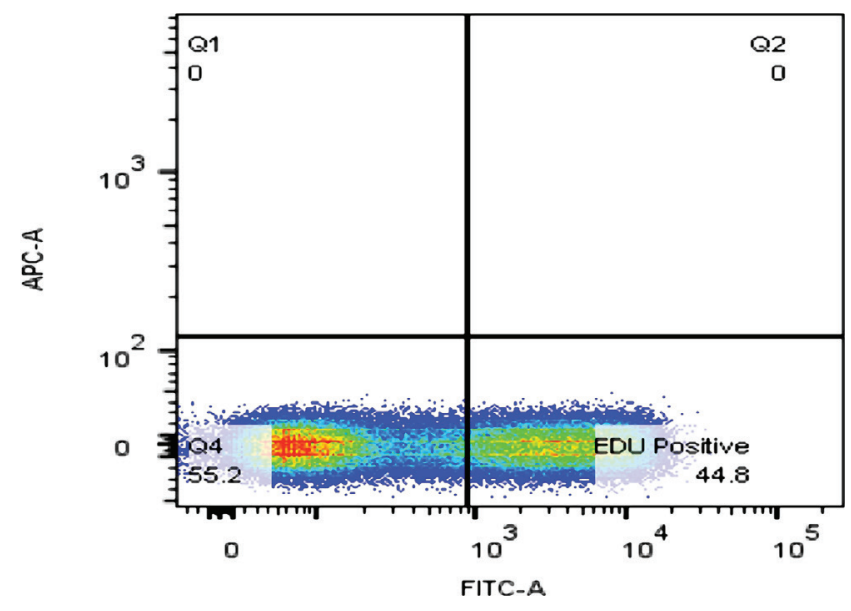

j.

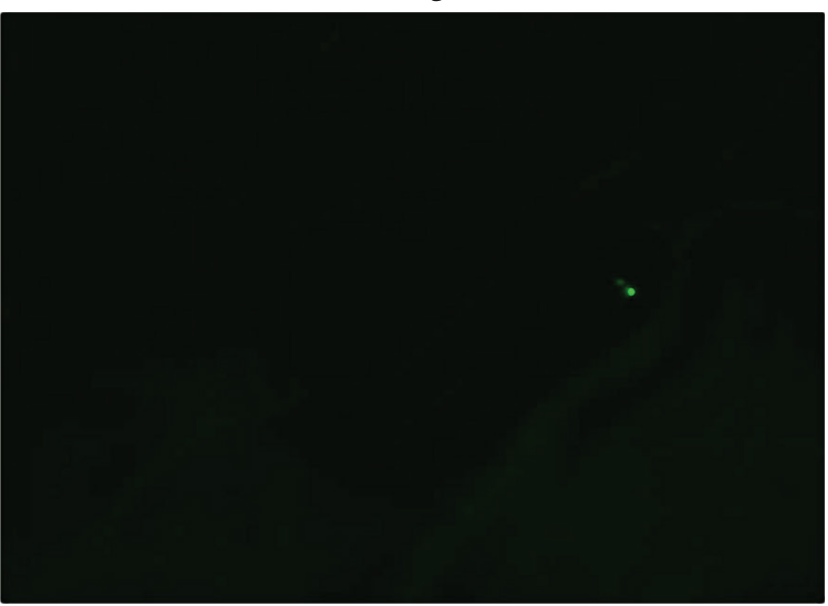

1.

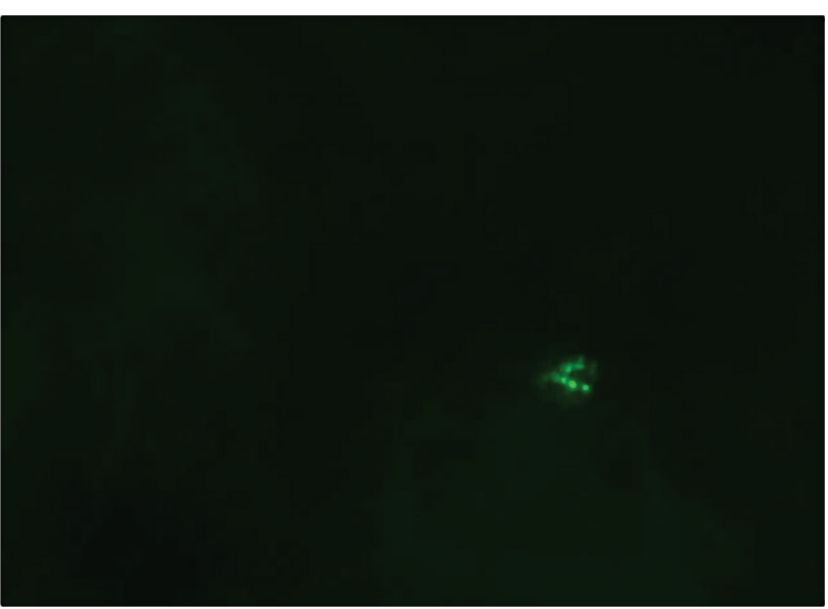

Figure 5. Continued.

the case of the apo a-LA and HALOA complex, which indicates the unfolding of the protein. The NMR spectrum of Apo a-LA progressively decreased upon titration with oleic acid, suggesting that there is a strong interaction between Apo a-LA and OA. However, the TEM result states that the addition of OA helps in the encapsulation of apo a-LA within OA, forming a unilamellar complex that attains size $(500 \mathrm{~nm})$, just like SNARE. Several reports documented that the t-SNARE's and secretory cargo complex or V-SNARE's are part of the conserved protein domains involved in a coalition of opposing membranes [39]. So the formulated complex with 


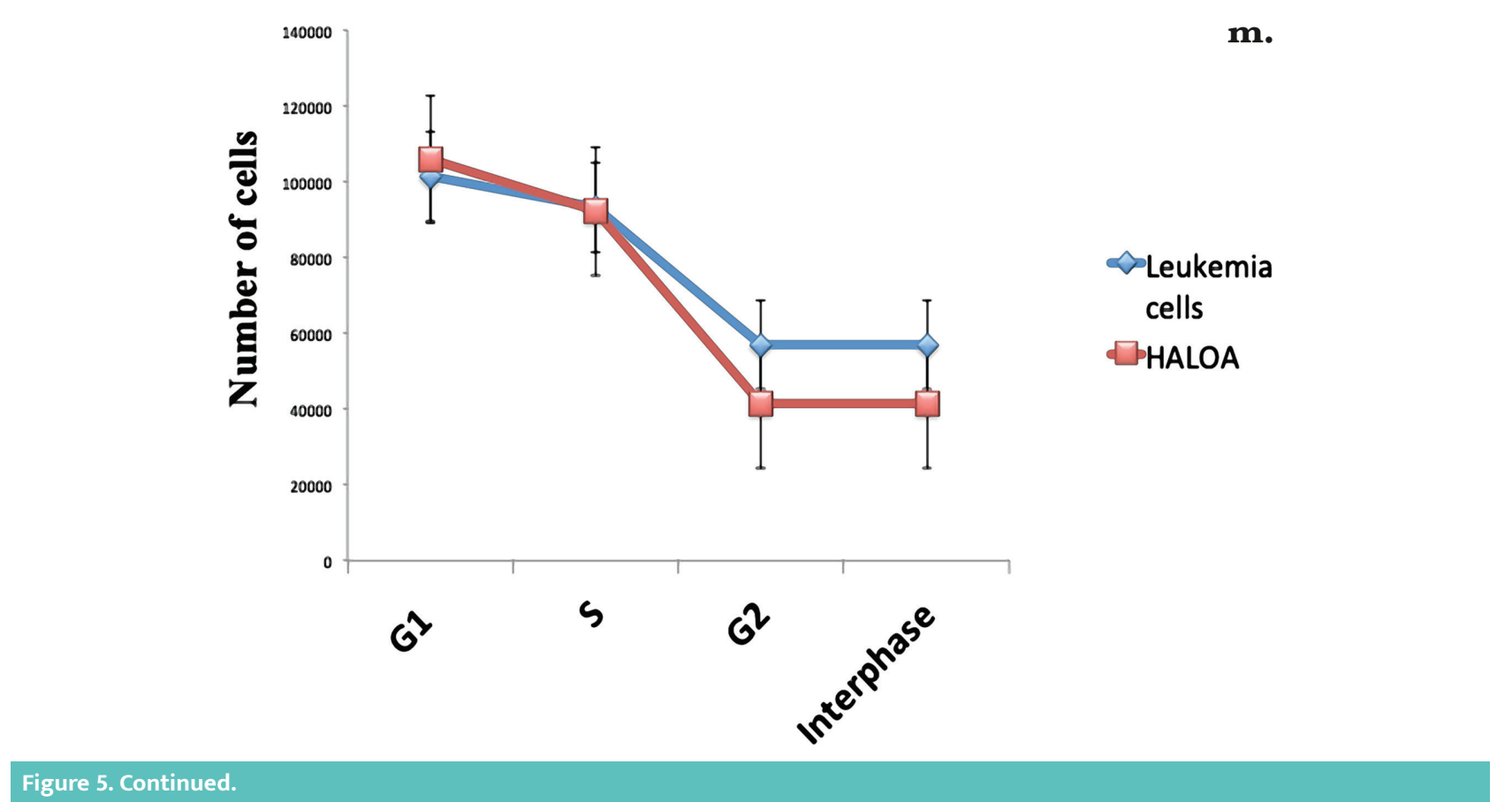

SNARE-like behavior will be helpful in effective targeting without loss of energy. The apoptosis induced by the HALOA complex was investigated based on the quintessential trait of programmed cell death, i.e., cell shrinkage, DNA fragmentation, and phosphatidylserine externalization. Our findings showed shrinkage in cell volume and enhanced granularity after treatment with the HALOA complex on K562 cells, which was not observed in OA and Apo a-LA. HALOA complex induces DNA fragmentation in leukemia cell lines, but there is no cell death or cytotoxicity in NIH cells (as control). The result indicated that the HALOA complex induces apoptosis in leukemia cells. The flow cytometry result showed a significant increase in apoptosis rate from $2.23 \%$ to $15.5 \%$ (p-value- 0.012 ), whereas in apo a-LA and OA treated cells, necrosis was higher than apoptosis. Further, the EdU assay indicated that maximum apoptosis occurs in the $\mathrm{G} 2 / \mathrm{M}$ phase by a $73.20 \%$ reduction in the proliferation rate. In leukemia, most of the cells have been found in the G2/M phase. The G2/M phase is tightly regulated by anti-apoptotic factor survivin by interacting with the DNA repair complex [40, 41] and is also involved in the cell-cycle-regulated expression. The microtubules of the mitotic spindle fiber consist of survivin, which helps maintain high fidelity of cell cycle checkpoints and transitions. Survivin expression is up-regulated in a cell cycle-dependent manner at the G2/M phase [38]. The expression of survivin was found to be significantly high in K562 cells, and treatment with HALOA complex along with their single constituent leads to lowering the expression of survivin. Still, the HALOA complex significantly reduces the expression of survivin and triggers apoptosis in leukemia cells. The total antioxidant is a positive indicator of apoptosis and was significantly elevated in cells treated with HALOA complex compared with apo-LA and OA. Increased production of TAC lower down inflammation in the cells $[27,28]$. We observed the expression level of IL-8 during treatment with the HALOA complex and found that only the complex can significantly reduce the expression level of IL-8. Il-8 increases the invasiveness and metastatic potential in leukemia cells.

\section{Table 2. Mean \pm SD (P-value).}

\begin{tabular}{|c|c|c|c|c|c|c|}
\hline No. & Parameters (Conc.) & $\begin{array}{c}\text { Control } \\
\text { (Mean士SD) }\end{array}$ & $\begin{array}{c}\text { Apo- } \alpha \text { LA } \\
(\text { Mean } \pm S D)\end{array}$ & $\begin{array}{c}\text { OA } \\
(\text { Mean } \pm S D)\end{array}$ & $\begin{array}{c}\text { HALOA } \\
\text { (Mean } \pm S D)\end{array}$ & P-value \\
\hline 1. & TAC (mM) & $0.018 \pm 0.0003$ & $0.038 \pm 0.002$ & $0.061 \pm 0.005$ & $0.113 \pm 0.013$ & $\begin{array}{c}0.0061 \\
0.051 \\
0.0064\end{array}$ \\
\hline 2. & $\mathrm{IL}-8(\mathrm{pg} / \mathrm{mL})$ & $98.62 \pm 3.36$ & $76.59 \pm 1.02$ & $63.31 \pm 1.69$ & $43.83 \pm 2.75$ & $\begin{array}{l}0.048 \\
0.021 \\
0.05\end{array}$ \\
\hline 3. & Survivin (pg/mL) & $2990 \pm 43.13$ & $2573 \pm 67.88$ & $2666 \pm 45.25$ & $2346 \pm 1.12$ & $\begin{array}{l}0.027 \\
0.003 \\
0.006\end{array}$ \\
\hline
\end{tabular}




\section{JOURNAL of MEDICINE and LIFE}

a.

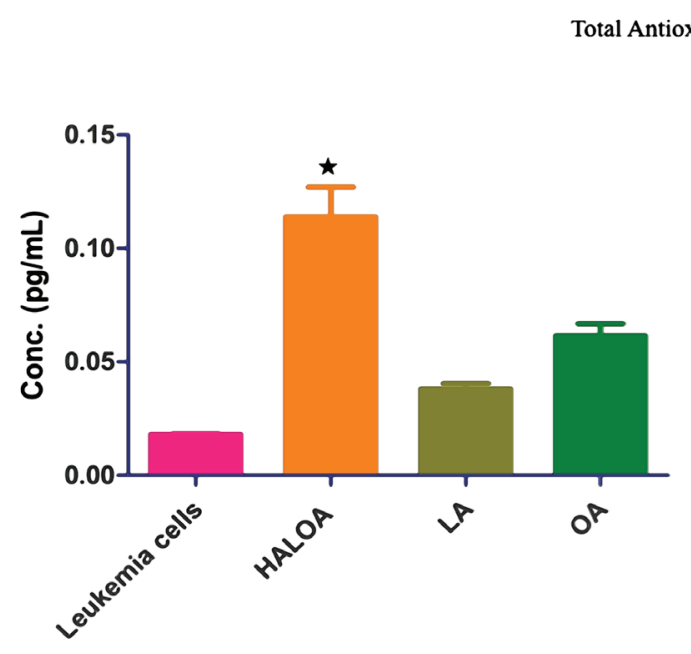

c.

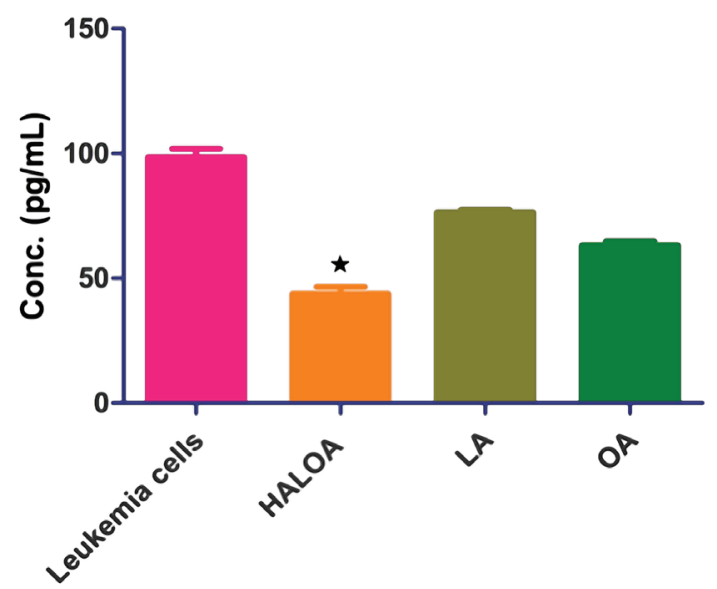

b.

Survivin

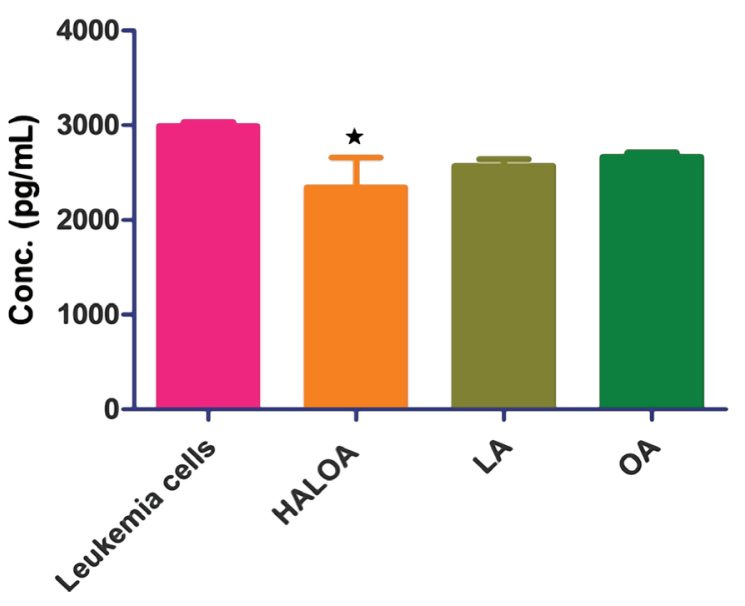

d.

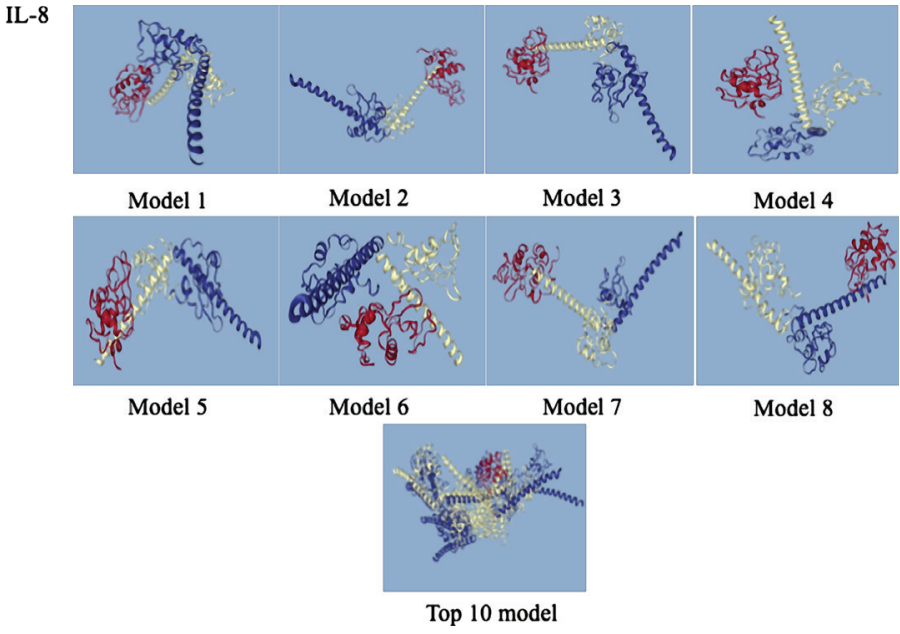

Figure 6. Effect of complex on TAC, survivin \& IL-8; (a) total antioxidant (TAC) was found to be significantly increased in HALOA $(0.5 \mathrm{mg} / \mathrm{mL})$ treated cells $(0.113 \pm 0.013 \mathrm{mM}, \mathrm{p}$-value; 0.0064$)$ and followed by LA (Apo $\alpha-\mathrm{LA}(1 \mathrm{mg} / \mathrm{mL}), 0 A(1 \mathrm{mg} / \mathrm{mL})(0.038 \pm 0.002 \mathrm{mM}, \mathrm{p}$-value; 0.0061 , $0.061 \pm 0.005 \mathrm{mM}, \mathrm{p}$-value; 0.051$)$ as compared with leukemia cells $(0.018 \pm 0.0003 \mathrm{mM})$. (b) the complex lowers down the expression of survivin as the conc. in leukemia cells $(2990 \pm 43.13 \mathrm{pg} / \mathrm{mL})$, HALOA $(0.5 \mathrm{mg} / \mathrm{mL})$ treated cells $(2346 \pm 1.12 \mathrm{pg} / \mathrm{mL}$, p-value; 0.006$)$, LA (Apo $\alpha$-LA $(1 \mathrm{mg} / \mathrm{mL})(2573 \pm 67.88 \mathrm{pg} / \mathrm{mL}$, p-value; 0.027$)$, and OA $(1 \mathrm{mg} / \mathrm{mL})(2666 \pm 45.25 \mathrm{pg} / \mathrm{mL}$, p-value; 0.003). (c) effect of complex on inflammation factor (IL-8) in leukemia cells (98.62 $\pm 3.36 \mathrm{pg} / \mathrm{mL})$, HALOA $(0.5 \mathrm{mg} / \mathrm{mL})(43.83 \pm 2.75 \mathrm{pg} / \mathrm{mL}$, p-value; 0.05), LA (Apo $\alpha$-LA (1 mg/mL) $(76.59 \pm 1.02 \mathrm{pg} / \mathrm{mL}$, p-value; 0.048$)$, and $\mathrm{OA}(1 \mathrm{mg} / \mathrm{mL})(63.31 \pm 1.69 \mathrm{pg} / \mathrm{mL}$, p-value; 0.021$)$. (d) the expression level of survivin and their association with HALOA complex, after G2/M cell cycle assessment; the docking result on the site of Thr 34 is a central part of viability after phosphorylation expression level of surviving significantly decreased in the treatment with complex $(p=0.034, p=0.023$, and $p=0.033)$. All the results are presented in the form of Mean \pm SD. The graph is plotted with $S D\left({ }^{*} p<0.05\right)$.

So, from our result, we can infer that the complex can inhibit the metastasis in myeloid leukemia cells by elevating the expression of IL-8. Furthermore, the in silico study validated our result performed by docking, which demonstrates that the complex can block the phosphorylated (Thr-34) site of survivin. The survivin expression is high in most cancers, which correlates with inhibition of apoptosis and leads to resistance towards chemotherapy and aggressiveness of cancers. The HALOA complex will be helpful in the treatment of resistant myeloid leukemia by targeting the survivin. We found a strong correlation between IL-8, survivin, and TAC using the Pearson correlation method. IL-8 and survivin were positively correlated (Pearson correlation 0.754 , sig. (2-tailed) 0.246 with N=4). TAC is negatively correlated with IL-8 and survivin (Pearson correlation -0.672 and -0.481, signal (2-tailed) 0.328 and 0.519 respectively with $\mathrm{N}=4$ ). Consequently, we can speculate that an increase in TAC level decreases the expression of IL-8, an important parameter for angiogenesis and survivin, as shown in Figure 7. The overall outcome reveals the multifaceted role of the HALOA complex with the potential to target the survivin, hampering the growth of cancer cells, increasing the TAC to counter the effect of oxidative stress, and does not allow the cell to become anoikis resistant. 


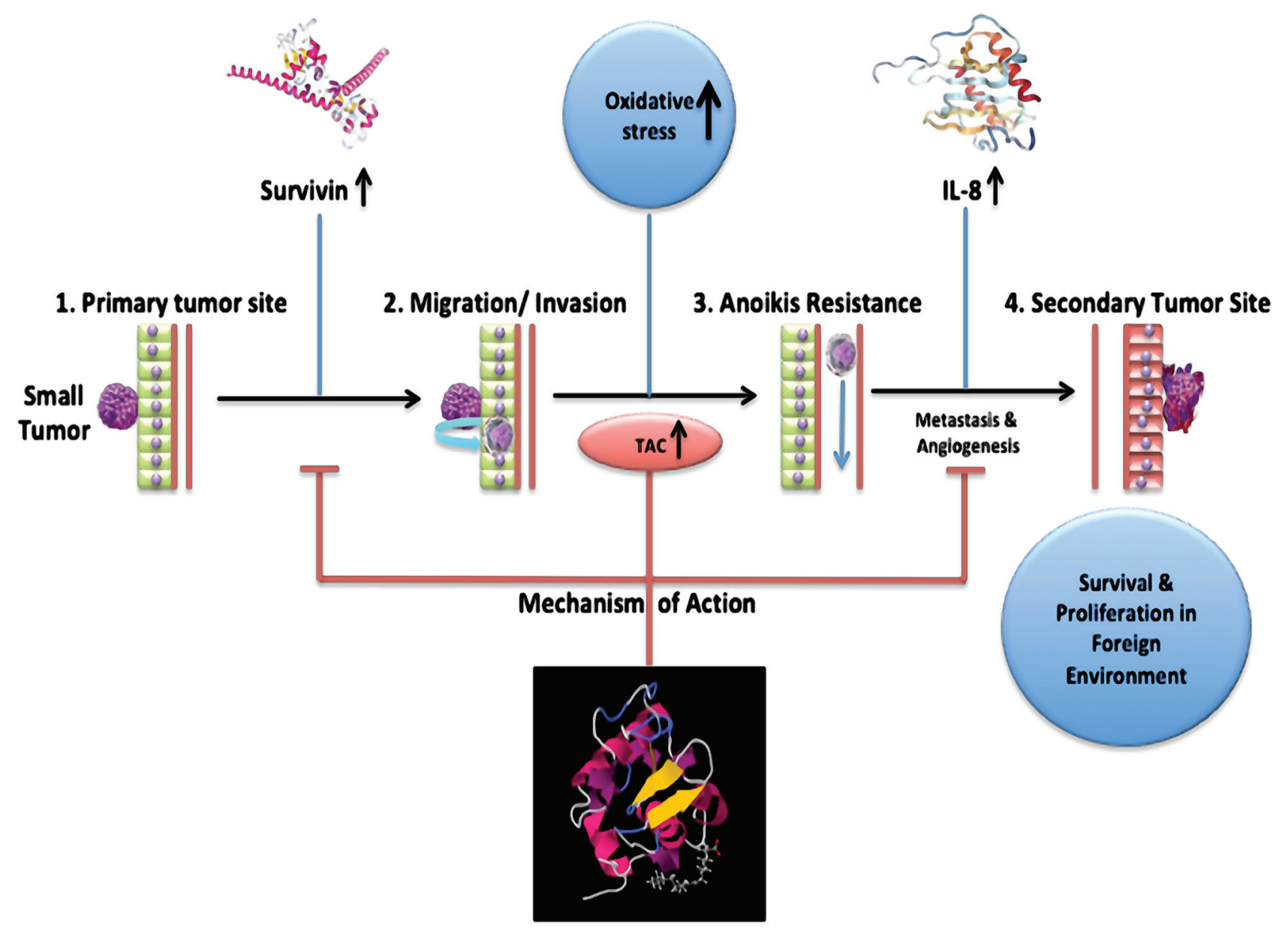

HALOA Complex

\section{CONCLUSION}

Overall, this study indicates the role of the HALOA complex as a new therapeutic target for drug-resistant chronic myeloid leukemia (CML) by enhancing total antioxidant activity and triggering apoptosis at the G2/M phase of cell cycle via lowering the expression level of survivin.

\section{ACKNOWLEDGMENTS}

\section{Conflict of interest}

The authors declare that there is no conflict of interest.

\section{Authorship}

V.S. and R.S. conceived and designed the research. V.S. conducted experiments. D.K. contributed new reagents or analytical tools. V.S, R.S., D.K., A.A.M, and A.K.T. analyzed the data. V.S. wrote the manuscript. All authors read and approved the manuscript, and all data were generated in-house. This study is part of the doctoral thesis of VS.

\section{Funding}

The work was supported by the Department of Biotechnology (BT/IN/Indo-US/Foldscope/39/2015) and ICMR (45/3/2019-Hae/ BMS) India. 


\section{JOURNAL of MEDICINE and LIFE}

\section{REFERENCES}

1. Singh V, Singh R, Mahdi AA. in-silico analysis of essentia amino acids of Alpha-lactalbumin in different species and its association with regulatory proteins for the normal cellula metabolism for growing newborn. International Journal of Emerging Technologies and Innovative Research. 2019 Mar 6;3:191-05.

2. HÅKANssoN A, Zhivotovsky B, Orrenius S, Sabharwal $\mathrm{H}$, Svanborg C. Apoptosis induced by a human milk protein Proceedings of the National Academy of Sciences. 1995 Aug 15;92(17):8064-8.

3. Köhler C, Håkansson A, Svanborg C, Orrenius S, Zhivotovsky B. Protease activation in apoptosis induced by MAL. Experimental cell research. 1999 Jun 15;249(2):260-8.

4. Green KA, Streuli CH. Apoptosis regulation in the mammary gland. Cellular and Molecular Life Sciences. 2004 Jul 1;61(15):1867-83.

5. Svensson M, Sabharwal H, Håkansson A, Mossberg AK, Lipniunas P, Leffler H, Svanborg C, Linse S. Molecular characterization of a-lactalbumin folding variants that induce apoptosis in tumor cells. Journal of Biological Chemistry. 1999 Mar 5;274(10):6388-96.

6. Permyakov SE, Knyazeva EL, Leonteva MV, Fadeev RS, Chekanov AV, Zhadan AP, Håkansson AP, Akatov VS, Permyakov EA. A novel method for preparation of HAMLET-like protein complexes. Biochimie. 2011 Sep 1;93(9):1495-501.

7. Svensson M, Håkansson A, Mossberg AK, Linse S, Svanborg C. Conversion of a-lactalbumin to a protein inducing apoptosis.

Proceedings of the National Academy of Sciences. 2000 Apr 11;97(8):4221-6.

8. Svanborg C, Ågerstam H, Aronson A, Bjerkvig R Düringer C, Fischer W, Gustafsson L, Hallgren O, Leijonhuvud I, Linse S, Mossberg AK. HAMLET kills tumor cells by an apoptosis-like mechanism - cellular, molecular, and therapeutic aspects. Advances in cancer research. 2003 Jan 1;88:1-29

9. Svensson M, Mossberg AK, Pettersson J, Linse S, Svanborg C. Lipids as cofactors in protein folding: Stereo-specific lipid-protein interactions are required to form HAMLET (human a-lactalbumin $\mathrm{m}$ ade le thal to $\mathrm{t}$ umor cells). Protein Science. 2003 Dec;12(12):2805-14

10. Kamijima T, Ohmura A, Sato T, Akimoto K, Itabashi M, Mizuguchi M, Kamiya M, Kikukawa T, Aizawa T, Takahashi M, Kawano K. Heat-treatment method for producing fatty acid-bound alpha-lactalbumin that induces tumor cell death. Biochemical and biophysical research communications. Biochemical and biophysi

11. Bañuelos S, Muga A. Binding of molten globule-like conformations to lipid bilayers structure of native and partially folded a-lactalbumin bound to model membranes. Journal of Biological Chemistr

1995 Dec 15;270(50):29910-5.

12. Halskau Ø, Frøystein NÅ, Muga A, Martmez A. The membrane-bound conformation of a-lactalbumin studied by NMR-monitored $1 \mathrm{H}$ exchange. Journal of molecular biology. 2002 Aug 2;321(1):99-110.

13. Halskau Ø, Underhaug J, Frøystein NÅ, Martínez A Conformational flexibility of a-lactalbumin related to its membrane binding capacity. Journal of molecular biology. 2005 Jun $24: 349(5): 1072-86$

14. Chenal A, Vernier G, Savarin P, Bushmarina NA Geze A, Guillain F, Gillet D, Forge V. Conformational states and thermodynamics of a-lactalbumin bound to membranes: a case study of the effects of $\mathrm{pH}$, calcium, lipid membrane curvature and charge. Journal of molecula biology. 2005 Jun 17;349(4):890-905.

15. Agasøster AV, Halskau Ø, Fuglebakk E, Frøystein NÅ, Muga A, Holmsen H, Martínez A. The interaction of peripheral proteins and membranes studied with a-lactalbumin and phospholipid bilayers of various compositions. Journal of Biological Chemistry. 2003 Jun 13;278(24):21790-7.

16. Chaudhuri D, Narayan M, Berliner IJ. Conformation-dependent interaction of a-lactalbumin with model and biological membranes: a spin-label ESR study The protein journal. 2004 Jan 1;23(1):95-101.

17. Ptitsyn OB. Molten globule and protein folding. InAdvances in protein chemistry, Vol, 46,1995, Academic Press, 83-229

18. Knyazeva EL, Grishchenko VM, Fadeev RS, Akatov VS, Permyakov SE, Permyakov EA. Who is Mr. HAMLET? Interaction of human a-lactalbumin with monomeric oleic acid. Biochemistry. 2008 Nov 12;47(49):13127-37.

19. Gaynon PS, Trigg ME, Heerema NA, Sensel MG, Sathe HN, Hammond GD, Bleyer WA. Children's Cancer Group trials in childhood acute lymphoblastic leukemia: 1983-1995. Leukemia. 2000 Dec;14(12):2223.

20. Altieri DC. Survivin apoptosis: an interloper between cell death and cell proliferation in cancer. Lab invest. 1999:11:1327-33.

21. Altieri DC. Survivin and apoptosis control. Advances in cancer research. 2003 Jan 1;88:31-52.

22. Ambrosini G, Adida C, Altieri DC. A novel anti-apoptosi gene, survivin, expressed in cancer and lymphoma. Nature medicine. 1997 Aug:3(8):917.

23. Velculescu VE, Madden SL, Zhang L, Lash AE, Yu J, Rago C, Lal A, Wang CJ, Beaudry GA, Ciriello KM, Cook $\mathrm{BP}$. Analysis of human transcriptomes. Nature genetics. 1999 Dec;23(4):387

24. Chakravarti A, Zhai GG, Zhang M, Malhotra R, Latham DE, Delaney MA, Robe P, Nestler U, Song Q, Loeffler J. Survivin enhances radiation resistance in primary human glioblastoma cells via caspase-independent mechanisms. Oncogene. 2004 Sep;23(45):7494.

25. Lu J, Tan M, Huang WC, Li P, Guo H, Tseng LM, Su XH, Yang WT, Treekitkarnmongkol W, Andreeff M, Symmans F. Mitotic deregulation by survivin in ErbB2-overexpressing breast cancer cells contributes to Taxol resistance. Clinical Cancer Research.
restover 2009 Feb 15;15(4):1326-34.

26. Li F, Ambrosini G, Chu EY, Plescia J, Tognin S, Marchisio PC, Altieri DC. Control of apoptosis and mitotic spindle checkpoint by survivin. Nature. 1998 Dec;396(6711):580.

27. Lakshminarayanan V, Beno DW, Costa RH, Roebuck KA. Differential regulation of interleukin-8 and intercellula adhesion molecule- 1 by $\mathrm{H}_{2} \mathrm{O}_{2}$ and tumor necrosis factor- $\mathrm{a}$ in endothelial and epithelial cells. Journal of Biological Chemistry, 1997 Dec 26:272(52):32910-8.

28. DeForge LE, Preston AM, Takeuchi E, Kenney J, Boxer LA, Remick DG. Regulation of interleukin 8 gene expression by oxidant stress. Journal of Biological Chemistry. 1993 Dec 5;268(34):25568-76.

29. DeForge LE, Fantone JC, Kenney JS, Remick DG. Oxygen radical scavengers selectively inhibit interleukin 8 production in human whole blood. The Journal of clinical investigation. 1992 Nov 1;90(5):2123-9.

30. Massion PP, Linden A, Inoue H, Mathy M, Grattan KM, Nadel JA. Dimethyl sulfoxide decreases

interleukin-8-mediated neutrophil recruitment in the airways. American Journal of Physiology-Lung Cellular and Molecular Physiology 1996 Nov 1;271(5): $838-43$.

31. Sanbrook J, Fritsch EF, Maniatis T. Molecular cloning: a laboratory manual. Cold Spring Harbor, NY, Cold Spring Harbor Laboratory, 1989;11:31.

32. Morgan BR, Artiss JD, Zak B. Calcium determination in serum with stable alkaline Arsenazo III and triglyceride clearing. Clinical chemistry. 1993 Aug 1;39(8):1608-12

33. Cistola DP, Hamilton JA, Jackson D, Small DM Ionization and phase behavior of fatty acids in water: application of the Gibbs phase rule. Biochemistry 1988 Mar 1;27(6):1881-8.

34. Edwards K, Silvander M, Karlsson G. Aggregate structure in dilute aqueous dispersions of oleic acid/sodium oleate and oleic acid/sodium oleate/egg phosphatidylcholine. Langmuir. 1995 Jul;11(7):2429-34.

35. Tolin S, De Franceschi G, Spolaore B, Frare E, Canton M, Polverino de Laureto P, Fontana A. The oleic acid complexes of proteolytic fragments of a-lactalbumin display apoptotic activity. The FEBS journal. 2010 Jan;277(1):163-73.

36. Chirita CN, Necula M, Kuret J. Anionic micelles and vesicles induce tau fibrillization in vitro. Journal of Biological Chemistry. 2003 Jul 11;278(28):25644-50.

37. Lücke C, Gantz DL, Klimtchuk E, Hamilton JA. Interactions between fatty acids and $\mathrm{a}$-synuclein. Journal of lipid research. 2006 Aug 1;47(8):1714-24.

38. Altznauer F, Martinelli S, Yousefi S, Thürig C, Schmid I, Conway EM, Schöni MH, Vogt P, Mueller C, Fey MF Zangemeister-Wittke U. Inflammation-associated cell cycle-independent block of apoptosis by survivin in terminally differentiated neutrophils. Journal of Experimental Medicine. 2004 May 17;199(10):1343-54

39. Wang T, Li L, Hong W. SNARE proteins in membrane trafficking. Traffic. 2017 Dec;18(12):767-75.

40. Okada H, Mak TW. Pathways of apoptotic and non-apoptotic death in tumour cells. Nature Reviews Cancer. 2004 Aug; $4(8): 592$

41. Speliotes EK, Uren A, Vaux D, Horvitz HR. The survivin-like C. elegans BIR-1 protein acts with the Aurora-like kinase AIR-2 to affect chromosomes and the Aurora-like kinase AfR-2 to affect chromosomes and the
spindle midzone. Molecular cell. 2000 Aug 1;6(2):211-23. 